\title{
Geochemistry and mineralogy of a silica chimney from an inactive seafloor hydrothermal field (East Pacific Rise, $18^{\circ} \mathrm{S}$ )
}

\author{
Dekov V.M. ${ }^{1,}{ }^{*}$, Lalonde S.V. ${ }^{2}$, Kamenov G.D. ${ }^{3}$, Bayon Germain ${ }^{1}$, Shanks W.C. ${ }^{4}$, Fortin D. ${ }^{5}$, \\ Fouquet Yves ${ }^{1}$, Moscati R.J. ${ }^{4}$
}

${ }^{1}$ Laboratoire de Géochimie et Métallogénie, Département Géosciences Marines, IFREMER, Z.I. Pointe du diable, BP 70, 29280 Plouzané, France

${ }^{2}$ CNRS UMR 6538 Laboratoire Domaines Océaniques, Institut Universitaire Européen de la Mer, Université de Brest, Place Nicolas Copernic, 29280 Plouzané, France

${ }^{3}$ Department of Geological Sciences, University of Florida, 241 Williamson Hall, Gainesville, FL 32611, USA

${ }^{4}$ U.S. Geological Survey, 973 Denver Federal Center, Denver, CO 80225, USA

${ }^{5}$ Department of Earth and Environmental Sciences, University of Ottawa, Advanced Research Complex, 25 Templeton St., Ottawa, Ontario K1N 6N5, Canada

*Corresponding author : V. M. Dekov, email address : Vesselin.Dekov@ifremer.fr

\begin{abstract}
:
An inactive vent field comprised of dead chimneys was discovered on the ultrafast East Pacific Rise (EPR) at $18^{\circ} \mathrm{S}$ during the research campaign NAUDUR with the R/V Le Nadir in December 1993. One of these chimneys was sampled, studied and found to be largely composed of silica-mineralized bacterial-like filaments. The filaments are inferred to be the result of microbial activity leading to silica $( \pm$ Fe-oxyhydroxide) precipitation. The chimney grew from the most external layer (precipitated $226 \pm 4 \mathrm{yr}$. B.P.) towards the central chimney conduit. Hydrothermal activity ceased $154 \pm 13 \mathrm{yr}$. B.P. and the chimney conduit was completely sealed. Mixing between an end-member hydrothermal fluid and seawater explains the $\mathrm{Sr}-\mathrm{Nd}$ isotopic composition of the chimney. Seawater was the major source of $\mathrm{Sr}$ to the chimney, whereas the dominant Nd source was the local mid-ocean ridge basalt (MORB) leached by the hydrothermal fluids. The mixing scenarios point to a dynamic hydrothermal system with fluctuating fluid compositions. The proportion of seawater within the venting fluid responsible for the precipitation of the silica chimney layers varied between 94 and $85 \%$. Pb-isotope data indicates that all of the $\mathrm{Pb}$ in the chimney was derived from the underlying MORB. The precipitation temperatures of the chimney layers varied between 55 and $71{ }^{\circ} \mathrm{C}$, and were a function of the seawater/end-member hydrothermal fluid mixing ratio. $\delta 30 \mathrm{Si}$ correlates with the temperature of precipitation implying that temperature is one of the major controls of the Si-isotope composition of the chimney. Concentrations of elements across the chimney wall were a function of this mixing ratio and the composition of the endmember hydrothermal fluid. The inward growth of the chimney wall and accompanying decrease in wall permeability resulted in an inward decrease in the seawater/hydrothermal fluid mixing ratio, which in turn exerted a control on the concentrations of the elements supplied mainly by the hydrothermal fluids. The silica chimney is significantly enriched in $U$, likely a result of bacterial concentration of $U$ from the seawater-dominated vent fluid. The chimney is poor in rare earth elements (REE). It inherited its REE distribution patterns from the parent end-member hydrothermal fluids. The dilution of the hydrothermal
\end{abstract}


fluid with over $85 \%$ seawater could not obliterate the particular REE features (positive Eu anomaly) of the hydrothermal fluids.

\section{Highlights}

Chimney is composed of silica-mineralized bacterial-like filaments. It grew from the most external layer towards the central chimney conduit. Proportion of seawater within the venting fluid varied between 94 and $85 \%$. Precipitation temperatures of the chimney layers varied between 55 and $71^{\circ} \mathrm{C}$. Chimney is rich in $U$ and poor in REE.

Keywords : Chimney, C-O-Si-Sr-Nd-Pb-Th-U isotopes, Hydrothermal, Seafloor, Silica

\section{Introduction}

X-ray amorphous silica is a common minor and rarely major constituent of modern seafloor hydrothermal deposits (Juniper and Fouquet, 1988, Jonasson and Perfit, 1999 and Hein et al., 2008). Occurrences of almost pure silica hydrothermal chimneys at the seafloor (Herzig et al., 1988, Urabe and Kusakabe, 1990, Stüben et al., 1994, Sun et al., 2012 and Jaeschke et al., 2014) and continental rifts (Shanks et al., 2005) are rarely reported. Unlike their sulphide counterparts, this type of underwater hydrothermal chimney has a low metal content and therefore, it is not economically attractive. As a consequence, silica hydrothermal chimneys have received little scientific interest. The few studies performed on them to date have focused on their mineralogy and geochemistry (major and some trace elements, isotopes of $\mathrm{O}$ and $\mathrm{Sr}$ ). The lack of precise age constraints on chimney formation and the limited trace element and isotope data (due to analytical challenges at the time of investigation) have 
resulted in somewhat speculative models for chimney formation. The scarce knowledge of recent seafloor hydrothermal silica chimney formation hampers the understanding of the formation of ancient silica chimneys preserved in the rock record (Chen et al., 2009). This is particularly critical when globally important events such as oceanic chemical perturbations (hypoxia, anoxia) and climate change are interpreted to be related to the increased hydrothermal input of silica to the ocean and subsequent massive precipitation of cherts (Chen et al., 2009).

Motivated by the insufficient knowledge of silica hydrothermal chimneys and both their significance for the interpretation of critical intervals of Earth's history and the indications that although metal-poor, these chimneys may concentrate some trace elements, we undertook a detailed trace element, isotopic, and geochronological investigation of a silica chimney collected at the EPR. The EPR segment where the chimney was recovered is located between the Garrett Fracture Zone (Garrett F.Z.) and the Easter Microplate (Fig. 1A). This part of the EPR was investigated during the research campaign NAUDUR, onboard the R/V Le Nadir operating the Deep Submersible Vehicle (DSV) Nautile in December 1993 (Auzende et al., 1994a, b; Fouquet et al., 1994; Auzende et al., 1996). The NAUDUR expedition was aimed at studying the interactions between tectonic, magmatic, and hydrothermal processes at an ultrafast spreading ridge. Hydrothermal fields at stage of activity cessation with formation of chimneys composed almost entirely of X-ray amorphous silica are among the large variety of hydrothermal manifestations described by the NAUDUR team (Fouquet et al., 1994).

Here we report the results of a study employing multiple mineralogical and geochemical tools (including $\mathrm{C}-\mathrm{O}-\mathrm{Si}-\mathrm{Sr}-\mathrm{Nd}-\mathrm{Pb}-\mathrm{Th}-\mathrm{U}$ isotope systematics) to decipher formation processes of this still poorly understood chimney type.

\section{Geological setting}

The EPR between the Garrett F.Z. and the Easter Microplate (Fig. 1A) is characterized by ultrafast and asymmetric spreading (Naar and Hey, 1989; DeMets et al., 1990; Perram et al., 1993; Cormier and Macdonald, 1994). The morphology of the ridge crest of this spreading segment is linear and homogeneous (Bäcker et al., 1985; Macdonald et al., 1988; Lonsdale, 1989; Perram et al., 1993; Scheirer et al., 1993; Cormier and Macdonald, 1994). The ridge axis is offset by several overlapping spreading centres (Lonsdale, 1989; Sinton et al., 1991). Ridge crest morphology variations, from a dome-shaped profile without an axial graben to a wide $(1-2 \mathrm{~km})$ and relatively deep $(50-100 \mathrm{~m})$ graben, were interpreted as being related to 
the existence of a shallow axial magmatic chamber (Macdonald and Fox, 1988; Scheirer et al., 1993).

The EPR axial graben between $18^{\circ} 11^{\prime} \mathrm{S}$ and $18^{\circ} 17^{\prime} \mathrm{S}$ (Fig. 1B) is approximately symmetric, with inner slopes bounded by en escalier faults oriented $\mathrm{N} 10^{\circ}-12^{\circ}$ with little basaltic rubble at their feet. Fissures were frequent on both sides of the graben and reached up to $20 \mathrm{~m}$ in width. The maximum depth of the axial graben ranged between $2681 \mathrm{~m}$ and 2689 $\mathrm{m}$. The central part was a wide (maximum $800 \mathrm{~m}$ ), almost flat depression mostly floored with relatively young lava flows (N-MORB). There were spurs bounded by fissures and faults, varying in width from meters to some tens of meters. Fissuring appeared to also affect the young lava at the seafloor as well as the hydrothermal deposits (dead chimneys), thus indicating that the youngest major activity occurring at this ridge segment was tectonic (Auzende et al., 1994a, b, 1996).

The outer slope of the western side was dominated by pillow lavas with sediment cover that represent the oldest volcanic products at this ridge segment. Steps inside the graben showed interlayered pillow, lobate, and sheet lavas, sometimes with small collapsed structures on top of small fault-bounded plateaus. Sheet and lobate lavas were dominant at the graben floor with the exception of the northernmost part, where pillow lavas and (less frequently) lobate lavas occurred. The sheet and lobate lavas observed at the seafloor along the southernmost cross section of the DSV Nautile dive \#16 showed a wide collapsed structure with well-preserved pillars and remnants of the original surface of the flow represented by thin lava slabs interconnecting pillars. This structure provides evidence for a wide collapsed lava lake representing the youngest volcanic filling of the graben. Collapse structures in lobate and sheet lavas were observed to the north, along the two E-W and W-E cross sections (Fig. 1B). This suggests that the bottom of the graben was mostly flat at the time of the outpouring of the sheet and lobate lavas and that lava pond(s) were formed. Emptying and subsequent collapse of the lava lake(s) was possibly due to higher depth of the seafloor in adjacent areas, or widening of the graben by tectonics, or both, promoting outflow of the lava. It is possible that the pillow lavas observed at the northernmost track of dive \#16 were related to a collapsed lava lake.

Ample evidence shows that the hydrothermal activity in the central graben was in a waning stage (Fouquet et al., 1994). Twenty hydrothermal sites were observed along $\sim 20 \mathrm{~km}$ of the eastern wall of the graben. Only two of them were active black smokers $\left(\mathrm{T} \leq 310^{\circ} \mathrm{C}\right)$. There was no diffuse flow discharge and no fauna around the vents. Inactive sulfide and silica chimneys (often broken and fallen) formed distinct alignments parallel to the eastern wall and 
were mostly located at the edge of small plateaus at the foot of the main fault wall. Yellow and reddish-brown sediments occurred as patches around the chimneys. The hydrothermal deposits were interpreted to be mature (Fouquet et al., 1994). Silica chimneys are considered to represent the end of a hydrothermal cycle (Fouquet et al., 1994). According to the scenario for the evolution of hydrothermal activity at an ultrafast spreading center (Fouquet et al., $1994)$ this ridge segment was on a tectonics-dominated $\left(3^{\text {rd }}\right)$ stage.

\section{Samples and methods of investigation}

The DSV Nautile dive \#16 track crossed and surveyed three inactive hydrothermal fields within the axial graben between $18^{\circ} 13^{\prime} \mathrm{S}$ and $18^{\circ} 14^{\prime} \mathrm{S}$ (Fig. 1B). Bright yellow, dead hydrothermal chimneys with a smooth partly dark grey surface (presumed to be composed of silica with a Mn-oxide coating) rested on lobate lavas and were scattered over a wide area (Fig. 2A). Some of them grew from cracks in the pillows, and yellow material similar to that composing the chimneys was visible underneath among the pillows.

The spire of an inactive chimney (\#ND 16-08; 18 $13.67 ' \mathrm{~S}, 113^{\circ} 21.57^{\prime} \mathrm{W}, 2682 \mathrm{~m} ; 50$ $\mathrm{cm} \times 10 \mathrm{~cm} ; 3 \mathrm{~kg}$ ) composed of porous, whitish-orange material was collected with the DSV Nautile manipulator (Fig. 2B). The core of the chimney was composed of more homogenous and lighter white material than the hard chimney wall around the core (Fig. 2C).

We selected five samples across the chimney after cutting a slice perpendicular to the chimney axis (Fig. 2C). The samples followed the (indistinct) internal concentric zoning of the chimney. Sub-samples from each sample were ground into a fine powder in an agate mortar for further mineralogical and geochemical analyses. Thin polished sections across the chimney wall were investigated by optical microscopy (Olympus BX60 polarizing microscope) for mineral composition and texture.

Secondary electron images (SEI) and energy dispersive X-ray spectra (EDS) were obtained on small $(\sim 0.5 \times 0.5 \mathrm{~cm})$ sub-samples from each sample using a FEI Quanta 200 scanning electron microscope $(\mathrm{SEM})(\mathrm{V}=10 \mathrm{kV}, \mathrm{I}=100 \mu \mathrm{A}$, electron beam diameter of $2 \mu \mathrm{m})$, after mounting the sub-samples on aluminium stubs using carbon tape and coating them with Au. X-ray mapping (in $\mathrm{Si} K_{\alpha}, \mathrm{Fe} K_{\alpha}$ and $\mathrm{U} M_{\alpha}$ lines) and analysis of elements with $\mathrm{Z} \geq 9$ were performed on C-coated polished thin sections using a Cameca SX 100 electron microprobe (EMP) $(\mathrm{V}=15 \mathrm{keV}, \mathrm{I}=20 \mathrm{nA}$, electron beam diameter of $2 \mu \mathrm{m})$. Standards used were: wollastonite $\left(\mathrm{Si} K_{\alpha}\right)$, andradite $\left(\mathrm{Fe} K_{\alpha}\right)$ and $\mathrm{UO}_{2}\left(\mathrm{U} M_{\alpha}\right)$, and detection limits (wt.\%) were 0.03 for $\mathrm{Si}, 0.04$ for Fe and 0.03 for U. Small sub-samples were embedded in EPON epoxy 
resin, sectioned with an ultra-microtome and observed using a Zeiss EM $912 \mathrm{X}$ energy filter model transmission electron microscope (TEM) operating at $120 \mathrm{kV}$.

The mineral composition of finely powdered sub-samples was determined by X-ray diffraction (XRD) analysis (Philips X-ray diffractometer PW 1820 with monochromatic Co $K_{\alpha}$ radiation) of random mounts with scans from 5 to $70^{\circ} 2 \theta$, with $0.01^{\circ} 2 \theta$ step, and $1 \mathrm{~s} / \mathrm{step}$. XRD patterns were interpreted by using the XPowder® software.

About $50 \mathrm{mg}$ of each sample were digested in conc. $\mathrm{HF}-\mathrm{HNO}_{3}$, immediately neutralized with $\mathrm{H}_{3} \mathrm{BO}_{3}$, and analyzed for major elements ( $\mathrm{Si}, \mathrm{Ti}, \mathrm{Fe}, \mathrm{Mg}, \mathrm{Na}, \mathrm{K}$ and $\mathrm{P}$ ) by Inductively Coupled Plasma Optical Emission Spectrometry (ICP-OES). Similar amounts ( $50 \mathrm{mg}$ ) of each sample were digested sequentially in conc. $\mathrm{HF}_{-}-\mathrm{HNO}_{3}$, aqua regia, and $6 \mathrm{M} \mathrm{HCl}$ and analyzed for trace element concentrations (Al, Ca, Mn, Sr, Li, Rb, Cs, Hf, Nb, Sc, Sn, W, V, $\mathrm{Cr}, \mathrm{Co}, \mathrm{Ni}, \mathrm{Cu}, \mathrm{Zn}, \mathrm{Cd}, \mathrm{Pb}, \mathrm{Ge}, \mathrm{Ga}, \mathrm{As}, \mathrm{Sb}, \mathrm{Se}, \mathrm{Mo}, \mathrm{Tl}$ and Re) with a Thermo Scientific Element2 High Resolution Inductively Coupled Plasma Mass Spectrometer (HR-ICP-MS) in $2 \% \mathrm{HNO}_{3}$ with In as an internal standard. The instrument was calibrated with multi-element solutions and the results verified against geostandards BHVO-2, IF-G, and GL-O treated in the same batch. REE, Y, $\mathrm{Zr}, \mathrm{Ba}$ and $\mathrm{U}$ concentrations were determined after total sample digestion, addition of a Tm spike and using a sample-standard bracketing procedure with BHVO-2 solutions (Barrat et al., 1996; Bayon et al., 2009a) during a separate analytical session on the Element2 HR-ICP-MS.

Total organic (TOC) and total inorganic (TIC) carbon content of the silica chimney was determined by analyzing carbon contents (Micro Cube elemental analyzer) of two batches of ground sub-samples: (1) untreated, and (2) after acid leaching. TOC was determined by analyzing residues after removal of carbonate by acid leaching of samples in $10 \% \mathrm{HCl}$ for 24 hours. Assuming that the majority of inorganic carbon in this type of seafloor deposit was in the crystal lattice of $\mathrm{Ca}(-\mathrm{Mg})$-carbonates, the TIC fraction was estimated as being the difference between the total carbon content of the untreated sub-sample and that of the acid leached sample (TOC). Total sulfur $\left(\mathrm{S}_{\text {tot }}\right)$, total organic sulfur $\left(\mathrm{S}_{\text {org }}\right)$ and total inorganic sulfur $\left(S_{\text {inorg }}\right)$ were measured following the same methodology and with the same analyzer. The routine analytical precision $(2 \sigma)$ was $\pm 0.1 \%$.

Carbon isotope compositions were similarly evaluated to determine the sources of $\mathrm{C}$ in the silica chimney. Samples (untreated and after acid leaching) and standards were weighed into tin capsules and loaded into an Isotope Cube elemental analyser interfaced to Delta Advantage isotope ratio mass spectrometer (IRMS). Samples and standards were flash combusted at about $1800^{\circ} \mathrm{C}$ (Dumas combustion) and the resulted gas products carried by $\mathrm{He}$ 
through preperatory columns optimised for analysis of $\mathrm{CO}_{2}$. The gases were separated by a "purge and trap" adsorption column and sent to the IRMS. The data are reported in $\delta$ notation where $\delta^{13} \mathrm{C}=\left(\left({ }^{13} \mathrm{C} /{ }^{12} \mathrm{C}\right)_{\text {sample }} /\left({ }^{13} \mathrm{C} /{ }^{12} \mathrm{C}\right)_{\text {standard }}-1\right) * 1000 . \delta^{13} \mathrm{C}\left(\delta^{13} \mathrm{C}_{\text {total }}\right.$ and $\left.\delta^{13} \mathrm{C}_{\text {organic }}\right)$ is reported as \%o vs. Vienna Pee Dee Belemnite (VPDB) and normalized to internal standards calibrated to International standards IAEA-CH-6, NBS-22, USGS-40 and USGS-41. The analytical precision was better than $0.2 \%$.

In order to estimate the temperatures of precipitation of the silica chimney layers and to reconstruct the thermal history of the chimney, we determined the O-isotope composition of the chimney samples. Oxygen isotope analysis of all five samples was carried out following reaction of silica with $\mathrm{BrF}_{5}$ and conversion of extracted $\mathrm{O}_{2}$ to $\mathrm{CO}_{2}$ (Clayton and Mayeda, 1963). Isotopic compositions were determined using a Finnigan MAT 252 IRMS by standard techniques. Precision and accuracy were assessed by replicate analysis of unknowns and the silica standard NBS-28. Isotopic compositions are reported conventionally as $\delta^{18} \mathrm{O}$ relative to Vienna Standard Mean Ocean Water (VSMOW) (Gonfiantini, 1978) and were reproducible to within $\pm 0.2 \%$.

In light of the proposed relationships between the temperature of precipitation and the Si isotope composition of siliceous chemical sediments (e.g., Geilert et al., 2014, 2015), Si isotope compositions of the silica chimney layers were determined by Thermo Scientific Neptune Multi-Collector Inductively Coupled Plasma Mass Spectrometer (MC-ICP-MS) after a digestion and purification procedure adapted from Georg et al. (2006). Measured isotopic ratios were corrected for mass bias by external $\mathrm{Mg}$ doping and normalized to the NBS28 standard. The accuracy of our Si-isotope measurements was assessed by analyzing a series of reference materials: $\mathrm{BHVO}-1\left(\delta^{30} \mathrm{Si}=-0.29 \%\right.$ $\left.\pm 0.242 \mathrm{sd}\right)$, Diatomite $\left(\delta^{30} \mathrm{Si}=1.16 \% \pm 0.20\right.$ $2 \mathrm{sd})$ and SGR-1 $\left(\delta^{30} \mathrm{Si}=0.01 \% \pm 0.282 \mathrm{sd}\right)$, in agreement with reference values from the literature: -0.33\%o (Abraham et al., 2008), 1.24\%o (Hughes et al., 2011) and 0.03\%o (Hughes et al., 2011), respectively.

To decipher the sources of $\mathrm{Sr}, \mathrm{Nd}$ and $\mathrm{Pb}$ and their relative proportions, we investigated the $\mathrm{Sr}-\mathrm{Nd}$-Pb-isotope compositions of the silica chimney. Strontium, $\mathrm{Nd}$, and $\mathrm{Pb}$ isotopic ratios were determined on a $\mathrm{Nu}$ Plasma MC-ICP-MS, following methods described in Kamenov et al. (2008). The reported ${ }^{87} \mathrm{Sr} /{ }^{86} \mathrm{Sr}$ ratios are relative to NBS 987 ${ }^{87} \mathrm{Sr} /{ }^{86} \mathrm{Sr}=0.71025(+/-0.00003,2 \sigma)$. The $\mathrm{Nd}$ isotopic compositions are relative to JNdi-1 ${ }^{143} \mathrm{Nd} /{ }^{144} \mathrm{Nd}=0.512115(+/-0.000018,2 \sigma)$. The $\mathrm{Pb}$ isotope data are relative to the following values of NBS 981: ${ }^{206} \mathrm{~Pb} /{ }^{204} \mathrm{~Pb}=16.937(+/-0.004,2 \sigma),{ }^{207} \mathrm{~Pb} /{ }^{204} \mathrm{~Pb}=15.490(+/-0.003,2 \sigma)$, and ${ }^{208} \mathrm{~Pb} /{ }^{204} \mathrm{~Pb}=36.695(+/-0.009,2 \sigma)$. 
In order to determine the temporal sequence of chimney layer precipitation, we dated the chimney layers using U-Th-isotope analysis. For U-Th analyses, $\sim 50 \mathrm{mg}$ of each sample were digested using both conc. $\mathrm{HNO}_{3}$ and conc. HF solutions, after addition of a mixed ${ }^{236} \mathrm{U}$ ${ }^{229} \mathrm{Th}$ spike. The $\mathrm{U}$ and $\mathrm{Th}$ fractions in each solution were purified using standard ion chromatographic methods (Bayon et al., 2009b) prior to the measurement of isotopic ratios using a standard-bracketing protocol on a Thermo Scientific Neptune MC-ICP-MS. The calculated ${ }^{230} \mathrm{Th}$ ages were corrected for minor contamination (i.e., $<4 \%$ of total ${ }^{230} \mathrm{Th}$ ) of inherited ${ }^{230} \mathrm{Th}$, assuming an initial ${ }^{232} \mathrm{Th} /{ }^{230} \mathrm{Th}$ ratio of 185,000 (i.e., a value for material near secular equilibrium).

\section{Results}

\subsection{Mineralogy}

X-ray diffraction analyses demonstrated that all five samples were composed of opal-A $\left(\mathrm{SiO}_{2} \cdot n \mathrm{H}_{2} \mathrm{O}\right.$ ): XRD patterns (not presented) showed only one broad, diffuse peak at $\sim 4.0 \AA$.

SEM-EDS observations revealed that the chimney is entirely composed of microbiallike silica filaments of two morphological types: simple straight (100-200 $\mu \mathrm{m}$ in length, 10-12 $\mu \mathrm{m}$ in diameter; Fig. 3A) and twisted ribbon-like (15-25 $\mu \mathrm{m}$ in length, 2-3 $\mu \mathrm{m}$ in diameter; Fig. 3B) filaments. Straight filaments dominate in the internal part of the chimney (samples \#\# ND 16-08-1, -2) whereas the twisted ribbon-like filaments dominate in the external part of the chimney (samples \#\# ND 16-08-4, -5). The twisted ribbon-like filaments frequently show small lepispheres attached to their surfaces and do not show indications of branching. They appear relatively homogenous in cross section and are not hollow. By contrast, the straight filaments are often branched and their axial zone looks hollow (Fig. 3C). Some of them are also coiled around each other (Fig. 3D). Optical microscope observations of thin sections of the internal part of the chimney wall (samples \#\# ND 16-08-1, -2) showed a simple anatomy for the straight filaments: a yellowish thread-like axial zone $(2-4 \mu \mathrm{m}$ in diameter) lining the inner hollow space, and likely composed of silica and Fe-oxyhydroxides [ $\mathrm{Si}=30.5$ wt.\%, $\mathrm{Fe}$ $=17.9$ wt. $\%, \mathrm{U}<0.03 \mathrm{wt} . \%, \mathrm{O}=39.9 \mathrm{wt} . \%$; low totals $(88.3 \mathrm{wt} . \%)$ due to presence of water; average of 8 point EMP analyses] enveloped by silica [Si $=43.8$ wt. $\%, \mathrm{Fe}=0.10$ wt.\%, $\mathrm{U}<$ 0.03 wt. $\%, \mathrm{O}=49.9 \mathrm{wt} . \%$; low totals $(93.8 \mathrm{wt} . \%)$ due to presence of water; average of 5 point EMP analyses] (Fig. 3E). X-ray mapping of the thin sections (Fig. 4) confirmed these observations. The filaments are often finely coated with Fe-oxyhydroxides (Fig. 3F). TEM 
observations of the most external chimney layer (\#ND 16-08-5) showed filament diameters varying from 0.2 to $2 \mu \mathrm{m}$ (Fig. 5A). The central zone of these filaments appeared to be composed of silica surrounded by a Fe-rich outer wall (EDS data not shown) (Fig. 5A). The open space among the filaments in the external layers (samples \#\# ND 16-08-4, -5) is sparsely impregnated with fine needles or crumpled sheets of Fe-oxyhydroxides (Fig. 5B).

\subsection{Major and trace element geochemistry}

Geochemical analyses confirm the XRD data, showing that the chimney is composed almost entirely of silica: $\mathrm{SiO}_{2}$ content varies between 88.2 and 94.0 wt.\%, with the lowest value in the most external layer (Table 1). Iron (expressed as $\mathrm{Fe}_{2} \mathrm{O}_{3}$; Table 1) is the second most abundant element after Si in the chimney, but the Fe concentrations decrease from the chimney exterior to the interior. No Fe-containing minerals were detected during the XRD studies even in the sample with a $\mathrm{Fe}_{2} \mathrm{O}_{3}$ content above the detection limits (>4\%) of the XRD method: $\left[\mathrm{Fe}_{2} \mathrm{O}_{3}\right]=5.4$ wt.\%, sample \# ND 16-08-5. It is reasonable to assume that $\mathrm{Fe}$ is mostly present as X-ray amorphous Fe-oxyhydroxides.

The distribution of the other elements across the chimney wall follows two major trends: (1) elements whose concentrations increase from the exterior to the interior ( $\mathrm{Ti}, \mathrm{Al}$, $\mathrm{Sn}, \mathrm{Ga}$ and U), and (2) elements whose concentrations generally decrease from the exterior to the interior $[\mathrm{Na}, \mathrm{K}, \mathrm{S}$ (total and its both components, organic and inorganic), $\mathrm{C}$ (both TOC and TIC), Mn, Sr, Ba, Li, V, Co, Zn, Cd, As, Sb and REE] (Table 1).

REE concentrations of the silica chimney are low: $\Sigma$ REE $<1 \mathrm{ppm}$ (Table 1). Chondritenormalized REE distribution patterns of the studied samples show positive Eu anomalies $\left(\mathrm{Eu} / \mathrm{Eu}^{*}>1\right)$, varying $\mathrm{Ce}$ anomaly (from negative to slightly positive), and slight enrichment of light REE relative to heavy REE ( $\left.\mathrm{La}_{\mathrm{CN} /} \mathrm{Lu}_{\mathrm{CN}}>1\right)$ (Table 1; Fig. 6A).

\subsection{Isotope composition}

The whole-rock $\mathrm{C}$ isotope compositions of the silica chimney samples are isotopically light, similar to the $\mathrm{C}$ isotope compositions of organic matter determined on decarbonated samples (Table 2).

The overall range of $\delta^{18} \mathrm{O}$ of the silica chimney samples is $26.6-29.6 \%$ and calculated temperatures of precipitation range between 55 and $71^{\circ} \mathrm{C}$ (Table 2). The variation in $\delta^{18} \mathrm{O}_{\text {silica }}$ is well above analytical uncertainty $( \pm 0.2 \%$ ) and certainly reflects small but real systematic 
variation across the chimney wall. Calculated temperatures are based on the quartz-water fractionation studies of Clayton et al. (1972), and in this study depend on three assumptions: (1) isotopic equilibrium between the silica and hydrothermal fluid, (2) precision, accuracy, and applicability of the quartz-water curve to the less-ordered silica in our samples, and (3) a

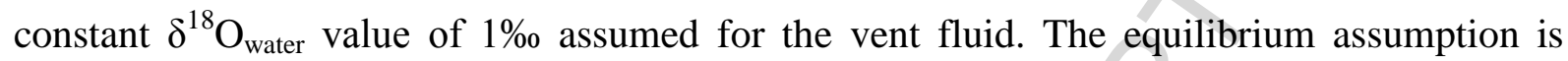
necessary, but the narrow range and systematic variation of $\delta^{18} \mathrm{O}_{\text {silica }}$ suggests equilibrium control, the Clayton et al. (1972) fractionation curve has been applied widely in low- and high-temperature systems, and it provides reasonable data compared to other temperature estimates. Assumption of a $\delta^{18} \mathrm{O}_{\text {water }}$ value introduces uncertainty, but was necessary as the chimney was inactive at the time of sampling and hydrothermal vent fluids could not be sampled. However, the range of mid-ocean ridge (MOR) vent fluid $\delta^{18} \mathrm{O}$ values is only from 0.0 to $2.2 \%$, averaging about $1 \%$ (Shanks, 2001). Moreover, hydrothermal fluids from black smoker chimneys nearby at $18^{\circ} 24^{\prime}-18^{\circ} 26^{\prime} \mathrm{S}$ on the EPR have $\delta^{18} \mathrm{O}_{\text {water }}$ values from 0.94 1.16\% (Shanks, 2001).

The $\mathrm{Si}$ isotope compositions $\left(\delta^{30} \mathrm{Si}\right)$ of the silica chimney samples are negative and range from $-2.24 \%$ to $-1.10 \%$ (Table 2 ). They fall within the isotope composition of similar hydrothermal silica deposits, such as the siliceous sediment at a Mariana black smoker and the silica sinters from Icelandic hot springs (Fig. 7). The $\delta^{30} \mathrm{Si}$ values of the silica chimney samples are lower than those of terrestrial magmatic rocks, seawater, and seafloor hydrothermal fluids (Fig. 7).

The ${ }^{87} \mathrm{Sr} /{ }^{86} \mathrm{Sr}$ ratios of the silica chimney samples range from 0.7081 to 0.7090 (Table 2), whereas the ${ }^{143} \mathrm{Nd} /{ }^{144} \mathrm{Nd}$ ratio ranges from 0.51288 to 0.51304 , with respective $\varepsilon \mathrm{Nd}$ values from 4.7 to 7.8 (Table 2). In contrast to $\mathrm{Sr}$ and $\mathrm{Nd}, \mathrm{Pb}$ isotopes show very small variations with values around 18.56 for ${ }^{206} \mathrm{~Pb} /{ }^{204} \mathrm{~Pb}, 15.60$ for ${ }^{207} \mathrm{~Pb} /{ }^{204} \mathrm{~Pb}$, and 38.07 for ${ }^{208} \mathrm{~Pb} /{ }^{204} \mathrm{~Pb}$ (Table 2).

${ }^{238} \mathrm{U}$ and ${ }^{232} \mathrm{Th}$ concentrations in the silica chimney samples vary between $\sim 8$ and $\sim 29$ ppm, and between $\sim 0.3$ and $\sim 3.6 \mathrm{ppb}$, respectively (Table 2). The ${ }^{232} \mathrm{Th} /{ }^{230} \mathrm{Th}$ ratios range from $\sim 300$ to $\sim 6500$, which correspond to $\left({ }^{230} \mathrm{Th} /{ }^{232} \mathrm{Th}\right)$ activity ratios between $\sim 28$ and 600 (Table 2). The studied samples display corrected $\delta^{234} \mathrm{U}_{\text {initial }}$ values similar to that of seawater $\left[\delta^{234} \mathrm{U}=146.6 \pm 2.5 \%\right.$; Robinson et al. (2004)], but a distinct trend towards slightly higher $\delta^{234} \mathrm{U}$ values was evident from the inner to the outer part of the chimney (from 147.7 \pm 0.9 to $154.4 \pm 1.2 \%$ ) (Table 2). Corrected ${ }^{230}$ Th ages range from about 150 to $230 \mathrm{yr}$ B.P., also exhibiting a trend towards younger ages from the outside in (Table 2). 


\section{Discussion}

\subsection{Hydrothermal silica chimneys from different geological settings}

The few reports on silica chimneys from seafloor active plate boundaries (Herzig et al., 1988; Urabe and Kusakabe, 1990; Stüben et al., 1994; Sun et al., 2012) and continental rifts (Shanks et al., 2005) suggest that these hydrothermal vent features have similar characteristics across different tectonic settings. The described chimneys were almost entirely composed of silica in the form of silicified bacterial-like filaments reminiscent of silicified bacteria in terrestrial silica sinters (e.g., Jones et al., 2004), had internal concentric textures around a sealed conduit, have red-brown to black outer surfaces, and were recently inactive, as is the case for the chimney described here. Although the geochemical data for comparison are scarce, we can infer that MOR silica chimneys seem to contain more $\mathrm{Si}$ and $\mathrm{U}$, and less $\mathrm{Fe}$, $\mathrm{Mg}, \mathrm{Al}, \mathrm{Ca}, \mathrm{Sr}, \mathrm{Ba}, \mathrm{Li}, \mathrm{Rb}, \mathrm{Cs}, \mathrm{W}, \mathrm{Ni}, \mathrm{As}, \mathrm{Sb}, \mathrm{Mo}$, and Tl, than chimneys from back-arc spreading centres (BASC) and continental rifts (Table 3). The major source of $\mathrm{Ba}, \mathrm{Ca}, \mathrm{Li}, \mathrm{Rb}$, and $\mathrm{Cs}$ are considered to be hydrothermal fluids [seawater being the second, but a minor source; German and Von Damm (2006)]. One of the major controls on the vent fluid chemistry is the leachable substrate composition (German and Von Damm, 2006). The contrasting substrate composition of MOR (tholeiites) and BASC (tholeiites to dacites and rhyolites) hydrothermal systems (Hékinian, 1982) results in different vent fluid chemistry (German and Von Damm, 2006). We may therefore hypothesise that the elevated $\mathrm{Ba}, \mathrm{Ca}, \mathrm{Li}$, $\mathrm{Rb}$, and Cs concentrations of BASC silica chimneys, relative to MOR silica chimneys, reflect their different vent fluid chemistries. Similarly, the increased contents of volatile elements, such as $\mathrm{As}, \mathrm{Sb}$, and $\mathrm{Tl}$, in the BASC silica chimneys implies increased input through direct magma degassing to felsic-hosted hydrothermal systems. High concentrations of $\mathrm{Ba}$ and $\mathrm{Ca}$ in the BASC silica chimneys and the occurrence of $\mathrm{Ba}$ and $\mathrm{Ca}$ in discrete minerals (barite and anhydrite, respectively) explain the slightly lower content of $\mathrm{Si}$ in these chimneys as a result of a "dilution" effect.

\subsection{Chronology of silica chimney formation}

Most of the previous studies on hydrothermal silica chimneys at the seafloor (Herzig et al., 1988; Stüben et al., 1994; Sun et al., 2012) and continental rifts (Shanks et al., 2005) have proposed various models for their growth. These models are largely based on the internal 
chimney texture and gradients in mineralogical and geochemical composition. A major flaw of each of these models is the lack of quantitative temporal constraints on chimney development: i.e., geochronological dating of consecutive precipitation events. Two studies have attempted to date different chimney parts, providing an approximate formation age of $\sim 1440 \mathrm{yr}$ for a chimney from the Galapagos Spreading Centre (Herzig et al., 1988) and 7500 yr for a chimney from the Mariana Back-Arc Spreading Centre (Stüben et al., 1994).

Uranium series disequilibrium dating of the different concentric layers of the studied silica chimney suggests that the chimney had grown from the most external layer (precipitated $226 \pm 4$ yr B.P.; Table 2) towards the central chimney conduit. This led to the complete sealing of the conduit around $154 \pm 13 \mathrm{yr}$ B.P. (Table 2) and cessation of hydrothermal fluid flow. The chimney lifetime was thus less than 100 years.

\subsection{Mechanism of silica precipitation}

Previous studies of hydrothermal silica chimneys (Herzig et al., 1988; Stüben et al., 1994; Shanks et al., 2005; Sun et al., 2012) based on the observations that underwater hydrothermal sites provide habitats for various microbial communities (Jannasch and Wirsen, 1981; Baross and Deming, 1985; Karl, 1995; Juniper et al., 1998; Cowen et al., 1999; Glazer and Rouxel, 2009; Davis et al., 2009; Sudek et al., 2009; Takai et al., 2009) suggest that silica chimney formation can be related to microbially mediated precipitation of silica and $\mathrm{Fe}$ oxyhydroxides.

Our observations (see section 4) show that silicified filaments, the main component of the studied silica chimney, have yellowish thread-like axial zones (composed of silica and Feoxyhydroxides) enveloped by silica that is often finely coated with Fe-oxyhydroxides (Figs 3E, F; 4A, B). Thus, if we suppose that a bacterial cell originally occupied the hollow axial zone of the filament (now empty after decay of organic matter; Fig. 3C), it is possible that it became coated with Fe-oxyhydroxides+silica, then encrusted by a thick silica envelope, and finally coated with Fe-oxyhydroxides (Fig. 3E, F). Similar observations have been reported for the low-temperature hydrothermal iron- and silica-rich precipitates in the CDE hydrothermal field, Lau Basin ( $\mathrm{Li}$ et al., 2012) and silica sinters in terrestrial hot springs (Jones et al., 2004).

Bacteria are known to secrete extracellular polymer substances (EPS) for attachment, colonization, and protection from environmental conditions. The EPS also acts as a reactive chemical surface for adsorption of dissolved $\mathrm{Fe}^{2+}$ and $\mathrm{SiO}_{4}{ }^{4-}$ (Fortin et al., 1998; Ueshima and 
Tazaki, 2001; Phoenix et al., 2003; Yee et al., 2003; Lalonde et al., 2005) that are abundant in the seafloor vent fluids (German and Von Damm, 2006). Surface complexation of the dissolved $\mathrm{Fe}^{2+}$ from the fluid to reactive sites (e.g., $\mathrm{COOH}^{-}, \mathrm{PO}_{4}{ }^{3-}$, and $\mathrm{OH}^{-}$groups) present within the bacterial cell wall and the EPS (Fortin et al., 1998) initiates precipitation of $\mathrm{Fe}$ oxyhydroxides. Dissolved $\mathrm{SiO}_{4}{ }^{4-}$ can adhere to positively charged $\mathrm{R}_{-} \mathrm{NH}_{3}{ }^{+}$groups present within the cell wall and initiate silica nucleation or alternatively adhere to negatively charged binding sites $\left(\mathrm{COOH}^{-}\right.$and $\mathrm{PO}_{4}{ }^{3-}$ groups) via a metal cation bridge (Urrutia and Beveridge, 1994; Fein et al., 2002). The presence of $\mathrm{Fe}^{3+}$-coatings on bacteria significantly increase silica sorption and precipitation rates, and the extent of $\mathrm{Si}$ sorption/precipitation increases with increasing $\mathrm{Fe}^{3+}$ concentrations (Urrutia and Beveridge, 1994).

We therefore argue that the observed filaments with "sandwich"-like internal textures, Fe-oxyhydroxides+silica - silica - Fe-oxyhydroxides (from inside out), are likely the result of microbial surfaces serving as substrates for the precipitation of silica and Fe-oxyhydroxide in the studied chimney. Phylogenetic analysis (e.g., using 16S rRNA) of associated microbes was not performed because the samples were not properly stored prior to analysis, i.e., they were not frozen at $-80^{\circ} \mathrm{C}$ shortly after sampling. Our arguments are therefore solely based on SEM and TEM observations, previous reports of similar precipitates (Jones et al., 2004; Li et al., 2012), and past laboratory studies of $\mathrm{Fe}-\mathrm{Si}$ interactions with bacteria (Urrutia and Beveridge, 1994; Fein et al., 2002). Furthermore, the twisted ribbon-like filaments are reminiscent of the stalks produced by microaerophilic Fe-oxidizing bacteria such as Gallionella, and it is interesting to note that these are primarily observed on the external layer of the chimney where the Fe content is highest. It is important to keep in mind, however, that similar structures may be produced abiotically (García-Ruiz et al., 2003), and that identification of silicified filaments as specific bacteria is fraught with difficulty, even when silicified and unsilicified examples are available in the same deposit (Jones et al., 2004).

A biological origin for the silicified filaments is suggested by the chimney $\delta^{13} \mathrm{C}_{\text {organic }}$ values, which are isotopically light (-28.37 to $-24.6 \%$; Table 2$)$, falling entirely within the range expected for autotrophic $\mathrm{CO}_{2}$ fixation by either phototrophic or chemotrophic bacteria. However, they are ambiguous with respect to an endogenous vs. exogenous origin of organic matter in the chimney. $\delta^{13} \mathrm{C}_{\text {total }}$ that is similar or only slightly higher than $\delta^{13} \mathrm{C}_{\text {organic }}$ (up to $23.9 \%$ ), indicates little to no contribution from isotopically heavier carbonates derived from seawater. Considering that the chimney grew from the outside inwards, it is unlikely that the isotopically light $\mathrm{C}$ isotope compositions (both total and organic values) of the chimney layers reflect inheritance from photosynthetically-derived organic matter settling through the water 
column. A chemoautotrophic origin for the isotopically light $\delta^{13} \mathrm{C}$ values is thus more likely, consistent with the idea that thermophilic microbes grew within the interior of the chimney during its formation and ultimately gave rise to the filamentous silica fabric observed in the chimney.

\subsection{Sources of $\mathrm{Sr}, \mathrm{Nd}$ and $\mathrm{Pb}$}

Strontium- and Nd- isotope compositions of the silica chimney samples show intermediate values indicative of mixing between the two possible $\mathrm{Sr}$ and $\mathrm{Nd}$ sources in the chimney: basaltic (leached and transported by hydrothermal fluids) and seawater (Fig. 8). The silica chimney was inactive at the time of sampling and no hydrothermal fluids were sampled. Therefore, for our interpretation we used the composition of hydrothermal fluids venting from the closest active chimneys as representative for the hydrothermal fluid composition of the silica chimney. Hydrothermal fluids of the closest chimneys "Tchao" and "Acorta" have Sr concentrations between 8 ppm and 15 ppm (Charlou et al., 1996). The lowest Sr concentration measured in the hydrothermal fluids of the surveyed area $\left(17^{\circ} \mathrm{S}-19^{\circ} \mathrm{S}\right)$ is $0.94 \mathrm{ppm}$ (Charlou et al., 1996). Neodymium concentrations of the hydrothermal fluids from the area vary between $0.11 \mathrm{ppb}$ and 1.1 ppb (Douville et al., 1999). The local deep-seawater has a Nd concentration of $0.0023 \mathrm{ppb}$ (Klinkhammer et al., 1983). We modelled four different mixing scenarios, with end-member hydrothermal fluid $\mathrm{Sr}$ concentrations ranging from $8 \mathrm{ppm}$ to $15 \mathrm{ppm}$ and $\mathrm{Nd}$ concentrations from $0.11 \mathrm{ppb}$ to $1.1 \mathrm{ppb}$, mixing with local deep-seawater (Fig. 8). As shown on Figure 8, no single mixing scenario between the hypothetical end-member hydrothermal fluid and seawater can explain the observed $\mathrm{Sr}-\mathrm{Nd}$ isotopic compositions of the silica chimney samples. Rather, the presented mixing scenarios for the observed Sr-Nd systematics indicate a dynamic system with changing composition of the hydrothermal fluid. Overall, the data show that a high proportion of seawater mixed with end-member hydrothermal fluid and contributed to the chimney composition. Seawater proportions within the venting fluid responsible for the precipitation of the silica chimney layers, from the outermost (\#ND 16-085) to the innermost (\#ND 16-08-1) samples, was 94, 92, 90, 85 and 92\%.

In contrast to $\mathrm{Sr}$ and $\mathrm{Nd}$, the $\mathrm{Pb}$-isotope composition of the silica chimney entirely overlaps with that of the local basalts and is similar to the Pb-isotope composition of the sulfide chimneys from the nearby active hydrothermal fields (Fig. 9). This indicates that all of the $\mathrm{Pb}$ in the silica chimney is derived from the underlying basalts. The observation that different isotopes provide different information about the element sources and their respective 
proportions can be explained by simple mass-balance calculations. Seafloor hydrothermal fluids have $\mathrm{Pb}$ concentrations ( $<20-3900 \mathrm{nmol} / \mathrm{kg}$ ) about four orders of magnitude higher than those of the seawater $(0.01 \mathrm{nmol} / \mathrm{kg})$ (German and Von Damm, 2006). Therefore, adding just a few percent of end-member hydrothermal fluid will completely swamp the $\mathrm{Pb}$ isotope signal of a mixture composed of seawater and hydrothermal fluid. On the other hand, the endmember hydrothermal fluids of the studied area have Sr concentrations $(10.7-189 \mu \mathrm{mol} / \mathrm{kg})$ comparable to those of local deep-seawater $(87 \mu \mathrm{mol} / \mathrm{kg}$ ) (Charlou et al., 1996). At the same time, Nd concentrations [739 - $6480 \mathrm{pmol} / \mathrm{kg}$; Douville et al. (1999)] of the end-member hydrothermal fluids of the studied area are one to two orders of magnitude higher than those of the local deep-seawater [16 pmol/kg; Klinkhammer et al. (1983)]. Therefore, a mixture of several percent end-member hydrothermal fluid and over 85 percent seawater will have a seawater-dominated $\mathrm{Sr}-$ and basalt-dominated $\mathrm{Nd}$-isotope composition. Thus, mixing calculations based on Sr-Nd-isotope compositions provide a more complete picture of the proportions of the two end-member fluids involved in the hydrothermal system.

\subsection{Thermal history of the silica chimney and temperature dependence of Si isotope} fractionation

The temperatures of silica precipitation calculated from the $\mathrm{O}$ isotope data (Table 2) generally increase from the oldest (outermost) layer (\#ND 16-08-5) inward (\#ND 16-08-2). The temperature of precipitation of the last deposited conduit filling (\#ND 16-08-1) drops down, suggesting cooling of the precipitating fluid. The relatively narrow range of $\delta^{18} \mathrm{O}_{\text {silica }}$ values and temperature of precipitation $\left(55-71^{\circ} \mathrm{C}\right)$ suggest seawater mixed with end-member hydrothermal fluids that have probably equilibrated with silica in volcanic glass and amorphous silica precipitated due to cooling at the seafloor. This remains true if one considers the widest possible range of $\delta^{18} \mathrm{O}$ values for mid-ocean ridge vent fluids $\left(49-79^{\circ} \mathrm{C}\right.$ for fluids with $\delta^{18} \mathrm{O}$ ranging from 0.0 to $2.2 \%$; Shanks et al., 2001). The reverse correlation of the temperature of silica precipitation with the proportion of seawater in the venting fluid (Fig. 10) suggests that the temperature of precipitation is a function of SW:EMHF mixing ratio. It also implies that the last stage of chimney development, the filling of the chimney conduit, occurred with seawater ingress into conduit (from above) leading to a decrease in the temperature of the vent fluid.

Overall, the temperatures of precipitation of the studied silica chimney layers $\left(55-71{ }^{\circ} \mathrm{C}\right)$ are similar to those at which the other seafloor silica chimneys formed $\left[32-68.5^{\circ} \mathrm{C}\right.$; Herzig et 
al. (1988), Stüben et al. (1994), Sun et al. (2012)] and slightly lower than the temperatures of formation of continental rift silica chimneys [78-164 ${ }^{\circ}$; Shanks et al. (2005)].

The fractionation of $\mathrm{Si}$ isotopes during silica precipitation appears to be closely related to the thermal history of the silica chimney. Previous work has demonstrated that the precipitation of amorphous silica favours the light isotope (De La Rocha et al., 1997; Ziegler et al., 2005; Basile-Doelsch, 2006). Recent laboratory experiments (Geilert et al., 2014) and field investigations (Geilert et al., 2015) have further constrained that low-temperature $\left(<100^{\circ} \mathrm{C}\right)$ precipitation of opaline silica from solution results in enrichment of the light isotope $\left({ }^{28} \mathrm{Si}\right)$ in the solid phase, leaving the co-existing solution enriched in the heavy isotope $\left({ }^{30} \mathrm{Si}\right)$. Additionally, adsorption experiments (Oelze et al., 2014) suggest that light Si isotopes are favored during Si adsorption onto crystalline minerals. Although we are not aware of any studies of $\mathrm{Si}$ isotope fractionation during microbial surface adsorption, and bacterial cell surfaces display a low affinity for aqueous silica (Fein et al., 2002), we may speculate that any $\mathrm{SiO}_{4}{ }^{4-}$ adsorption directly onto bacterial cell walls and/or EPS (sub-section 5.3) would also lead to $\mathrm{Si}$ isotope fractionation favouring more negative $\delta^{30} \mathrm{Si}$ values in the bacterially templated silica.

In other words, abiotic (and likely biotic) silica precipitation is accompanied by preferential uptake of lighter $\mathrm{Si}$ isotopes, yielding lower $\delta^{30} \mathrm{Si}$ than the remaining fluid (Geilert et al., 2015). After reaching a steady state, the selective incorporation of Si isotopes by the solid phase exhibits a clear temperature dependency: the lighter Si isotopes are preferentially incorporated, and apparent fractionation magnitudes increase with decreasing temperature (Geilert et al., 2014, 2015). Our data (Table 2) provide an important natural confirmation that the preferential incorporation of isotopically light Si occurs during the precipitation of silica at temperatures lower than $100^{\circ} \mathrm{C}$ (Fig. 7).

Alternatively, the observed $\delta^{30} \mathrm{Si}$ fluctuations across the chimney wall (Fig. 10) might be controlled by changes in the Si-isotope composition of the venting fluid, thereby reflecting variable contributions of seawater versus end-member hydrothermal fluid. However, considering both the presumed Si-isotope signatures of the regional deep seawater $\left(\delta^{30} \mathrm{Si}=\right.$ $+1.2 \%$; de Souza et al., 2012) and seafloor hydrothermal fluids $\left(\delta^{30} \mathrm{Si}=-0.3 \%\right.$; De La Rocha et al., 2000), one would expect that the temporal $\delta^{30} \mathrm{Si}$ increase observed across the chimney wall corresponds to higher proportions of seawater in the vent fluid, hence opposite to the observed trend (Fig. 10). Based on the above considerations, the correlation between inferred silica precipitation temperatures (based on $\delta^{18} \mathrm{O}$ ) and solid phase $\delta^{30} \mathrm{Si}$ values in the silica 
chimney reaffirms the idea that temperature may exert a major control on the $\mathrm{Si}$ isotope composition $\left(\delta^{30} \mathrm{Si}\right)$ of siliceous chemical deposits (Fig. 10).

\subsection{Geochemistry of the silica chimney wall}

The temporal scenario for silica chimney formation proposed here, along with the isotope data speaking to sources of $\mathrm{Sr}, \mathrm{Nd}$ (and likely the other $\mathrm{REE}$ ), and $\mathrm{Pb}$, provide important information on the geochemical evolution of the chimney wall. Concentrations of elements across the chimney wall are a function of both the mixing proportions of two source fluids (seawater proportions of 94, 92, 90, 85 and $92 \%$, from the oldest to the youngest layer) and the composition of the end-member hydrothermal fluid (assuming seawater composition did not change dramatically during the chimney formation; i.e., between $226 \pm 4$ and $154 \pm 13$ yr B.P.).

\subsubsection{Iron, $M n$ and $S$}

Concentrations of $\mathrm{Fe}$ and $\mathrm{Mn}$, two major metals substantially enriched in hydrothermal fluids, decrease from the oldest, outermost layer (\#ND 16-08-5) to the most recent, innermost layer (\#ND 16-08-1) (Table 1). The most ready explanation for this observation is a compositional variation of the hydrothermal fluid through time: i.e., a decrease in both Fe and Mn concentrations in the vent fluid. However, chimney growth (inward in this case) will result not only in a thicker, but also in a denser wall (macroscopically observed; see second paragraph, section 3). This would lead to a temporal decrease in wall permeability and consequently to an inward decrease in the mixing ratio of seawater and hydrothermal fluid and thus less dilution of the hydrothermal Fe and Mn supply. This is supported by the Sr-Ndisotope data (with the exception of the youngest inner chimney, filled conduit). Silica likely continued precipitating inward in the chimney, but mostly at the expense of conductive cooling, and likely less as a result of seawater/hydrothermal fluid mixing. We inferred (section 4) that in the studied chimney, Fe was likely mostly present as Fe-oxyhydroxides. The Mn content in the chimney is so low $\left(0.03 \mathrm{wt} . \% \mathrm{MnO}_{2}\right.$ in the most rich in Mn layer \#ND 16-08-5, Table 1) that we could not detect any Mn-mineral using the XRD (detection limits $>4 \mathrm{wt} . \%$ ). We therefore assume that the major part of Mn in the silica chimney was present as Mn-oxyhydroxides rather than as impurity in the silica. Further, we speculate that the decreased seawater/hydrothermal fluid ratio towards the interior of the chimney (as a result of development of a denser outer wall), might further lead to a decrease in the dissolved $\mathrm{O}_{2}$ flux 
from seawater to the chimney interior. Some dissolved hydrothermal Fe and $\mathrm{Mn}$ would be expected to precipitate as Fe-Mn-oxyhydroxides in the inner chimney zone, but progressive suppression of $\mathrm{O}_{2}$ transport across the chimney wall during growth would favour their solubility in reduced form. Further, dissolved Fe and Mn would move outward as a result of diffusion caused by the dramatic difference in Fe and $\mathrm{Mn}$ concentrations of vent fluid and ambient seawater (German and Von Damm, 2006), and would gradually precipitate upon encountering sufficient $\mathrm{O}_{2}$ in the outer layers (due to higher proportions of seawater). The part of the chimney deposited last, i.e., the conduit filling (\#ND 16-08-1), shows an increased seawater proportion of $92 \%$. Conduit filling marks the last stage of chimney growth, with cessing hydrothermal activity and notably increased seawater flux into the chimney conduit as inferred from vent fluid temperature calculations. This would mean an increased dissolved $\mathrm{O}_{2}$ flux and possibly increased Fe-Mn-oxyhydroxide precipitation. However, $\mathrm{Fe}$ and $\mathrm{Mn}$ concentrations in the conduit filling are lowest (\#ND 16-08-1; Table 1), perhaps as the result of higher dilution of the hydrothermal fluid by seawater or decreased $\mathrm{Fe}$ and $\mathrm{Mn}$ concentrations in the hydrothermal fluid.

There exists a correlation of the temporal distribution of $S_{\text {inorg }}$ (and $S_{\text {tot }}$ ) with the distributions of $\mathrm{Fe}, \mathrm{Ca}, \mathrm{Ba}, \mathrm{Zn}, \mathrm{Cd}, \mathrm{Pb}$, $\mathrm{As}$ and $\mathrm{Sb}$, which all decrease from the oldest outer layer to youngest inner layer (Table 1). This suggests that although our XRD studies did not reveal the presence of $\mathrm{Fe}, \mathrm{Zn}, \mathrm{Cd}, \mathrm{Pb}$, As or Sb sulfides, nor $\mathrm{Ca}$ or Ba sulfates, we cannot completely rule out the presence of trace $(<4 \%)$ amounts of these minerals in the chimney. A decrease in the $\mathrm{H}_{2} \mathrm{~S}$ content of the vent fluid as the hydrothermal system waned might have favoured the precipitation of traces of $\mathrm{Fe}, \mathrm{Zn}, \mathrm{Cd}, \mathrm{Pb}, \mathrm{As}$ and $\mathrm{Sb}$ sulfides more towards the beginning of chimney growth.

\subsubsection{Barium and $\mathrm{Ca}$}

A similar scenario would explain the inward (temporal) decrease of the $\mathrm{Ba}$ concentrations in the silica chimney (Table 1). Assuming that $\mathrm{Ba}$ was mostly present as $\mathrm{BaSO}_{4}$ (barite) like in other seafloor hydrothermal chimneys (German and Von Damm, 2006), we may infer that the inward decrease of the chimney wall permeability through silica precipitation decreased the seawater supply of $\mathrm{SO}_{4}{ }^{2+}$ [end-member hydrothermal fluids of MOR hydrothermal systems do not contain $\mathrm{SO}_{4}{ }^{2+}$; German and Von Damm (2006)] needed for $\mathrm{BaSO}_{4}$ precipitation. Dissolved $\mathrm{Ba}$ that had not been immobilized through $\mathrm{BaSO}_{4}$ precipitation in the internal zone ( $\mathrm{SO}_{4}{ }^{2+}$ deficiency) would diffusively move outward [seawater contains 1-2 orders of magnitude less Ba than the hydrothermal fluid of ultrafast 
spreading centres; German and Von Damm (2006)] and would progressively precipitate upon reaction with seawater $\mathrm{SO}_{4}{ }^{2+}$. Ca distribution across the chimney wall (Table 1) may also be explained by this model if we assume (based on the correlation of $\mathrm{Ca}$ and $\mathrm{S}_{\text {inorg }}$ ) that $\mathrm{Ca}$ was mostly present in the $\mathrm{CaSO}_{4}$ (anhydrite) crystal lattice.

\subsubsection{Phosphorus, $\mathrm{Li}, \mathrm{V}, \mathrm{Co}, \mathrm{Zn}, \mathrm{Cd}, \mathrm{Pb}, \mathrm{As}$ and $\mathrm{Sb}$}

Distributions of $\mathrm{P}, \mathrm{Li}, \mathrm{V}, \mathrm{Co}, \mathrm{Zn}, \mathrm{Cd}, \mathrm{Pb}, \mathrm{As}$ and $\mathrm{Sb}$ across the chimney wall generally follow that of $\mathrm{Fe}$ and $\mathrm{Mn}$, i.e., decreasing inwards with a slight increase in the chimney conduit filling (Table 1). With the exception of $\mathrm{P}$ and $\mathrm{V}$, these elements are mostly supplied by the hydrothermal fluids in the seafloor vents (Gurvich, 2006; German and Von Damm, 2006). Zinc, $\mathrm{Cd}, \mathrm{Pb}$, As and $\mathrm{Sb}$ may form their own minerals (e.g., sulfides and sulfosalts) in reducing hydrothermal environments. However, under predominantly oxic conditions like that inferred for the silica chimney vent fluid (>85\% seawater) these elements (along with $\mathrm{P}, \mathrm{Li}, \mathrm{V}$ and Co) seem to be mostly scavenged by Fe-Mn-oxyhydroxides (e.g., Gurvich, 2006) and are rarely present as discrete sulfides and sulfosalts. Indeed, their distribution across the chimney wall follows that of $\mathrm{Fe}$ and $\mathrm{Mn}$. The minor increase in $\mathrm{P}$ and $\mathrm{V}$ contents in the chimney conduit filling may be explained with the increased proportion of seawater (92\%) in the vent fluid, whereas a similar increase in the concentrations of $\mathrm{Li}, \mathrm{Co}, \mathrm{Zn}, \mathrm{Cd}, \mathrm{Pb}, \mathrm{As}$ and $\mathrm{Sb}$ may be better attributed to changes in hydrothermal fluid chemistry, e.g. less important removal of these elements in the subsurface as hydrothermal activity waned.

\subsubsection{Aluminium, $R b$ and $G a$}

Concentrations of $\mathrm{Al}, \mathrm{Rb}$ and $\mathrm{Ga}$ increase inward across the silica chimney wall (Table 1). Al-containing minerals were not detected in the chimney. Rubidium and Ga do not form their own minerals in seafloor hydrothermal environments. These three elements do not appear to be scavenged by Fe-Mn-oxyhydroxides either (Gurvich, 2006). It is however possible that they are present as impurities in the silica: e.g, $\mathrm{Al}^{3+}$ substituting for $\mathrm{Si}^{4+}$ (Miyoshi et al., 2005). Hydrothermal fluids at ultrafast spreading centers contain more $\mathrm{Al}$ and $\mathrm{Rb}$ than ambient seawater (German and Von Damm, 2006). The inward growth of the silica chimney wall and its progressive decrease in permeability would have gradually decreased the dilution of hydrothermal fluid by seawater (with low $\mathrm{Al}$ and $\mathrm{Rb}$ concentrations) within the chimney. As a result, the concentrations of $\mathrm{Al}$ and $\mathrm{Rb}$ (and presumably $\mathrm{Ga}$ ) in the vent fluids, and consequently the $\mathrm{Al}$ and $\mathrm{Rb}$ impurities entrapped in the precipitated silica layers, will be a function of time (silica layer age), with the youngest layers capturing more $\mathrm{Al}$ and $\mathrm{Rb}( \pm \mathrm{Ga})$. 
Conversely, the increased proportion of seawater in the vent fluid that precipitated the conduit filling would have resulted in a decrease in the $\mathrm{Al}, \mathrm{Rb}$, and $\mathrm{Ga}$ concentrations. The observed steady increase of these concentrations (Table 1) perhaps reflects an increase in the parent end-member hydrothermal fluid at this late stage of chimney formation.

\subsubsection{Uranium}

Concentrations of $U$ in the studied chimney (8.61 - $28.8 \mathrm{ppm}$; Table 1) are similar to those of other underwater silica chimneys (1.03 - $5.95 \mathrm{ppm}$; Table 3), seafloor hydrothermal sulfides [1 - 40 ppm; Fouquet et al. (2010)], and seafloor metalliferous sediments [0.87 - 10.6 ppm at the EPR $14^{\circ} \mathrm{S}$ close to the location of the studied silica chimney (Fisher and Boström, 1969), up to 18.9 ppm at the TAG area of the Mid-Atlantic Ridge (Mills et al., 1994), and up to $45 \mathrm{ppm}$ (on a carbonate-free basis) at the FAMOUS area of the Mid-Atlantic Ridge (Scott et al., 1979)]. They are also comparable in U concentrations to anoxic marine sediments [4.3 47 ppm; Veeh (1967), Mangini and Dominik (1979), Weyer et al. (2008), Baturin (2011)]. Compared to the average U content of background deep-sea sediments [3 ppm; Veeh (1967)] it appears that all types of seafloor hydrothermal deposits (silica chimneys, sulfide chimneys and mounds, and metalliferous sediments) are significantly enriched in U. Investigations of the ${ }^{234} U /{ }^{238} U$ activity ratios of hydrothermal silica chimneys (Herzig et al., 1988; Stüben et al., 1994), seafloor hydrothermal sulfides (Lalou et al., 1989, 1995; Kuznetsov et al., 2011), metalliferous sediments (Scott et al., 1979; Mills et al., 1994) and anoxic sediments (Veeh, 1967; Mangini and Dominik, 1979) have shown that they are close to that of seawater $\left[{ }^{234} U{ }^{238} U_{\text {activity }}=1.144 \pm 0.002, \delta^{234} U=144 \pm 2\right.$; Chen et al. (1986a) $]$, indicating that seawater is the principal source of the elevated $U$ concentrations in these deposits. In the case of silica chimneys, sulfide chimneys, and metalliferous sediments, a hydrothermal input of $U$ (leached from the host rocks) may theoretically be expected. The observation that basalt-hosted sulfides contain less $U$ than the ultramafic-hosted sulfides [1 - 11 ppm vs. 6 - 40 ppm, respectively; Fouquet et al. (2010)] and that this clearly correlates with the U concentrations of the host rocks $\left[\mathrm{U}_{\mathrm{N}-\mathrm{MORB}}=0.014 \mathrm{ppm}, \mathrm{U}_{\mathrm{ultramafic} \text { rocks }}=0.026 \mathrm{ppm}\right.$; Anderson (1989)] implies that $U$ concentrations in the seafloor hydrothermal systems may be controlled by the $U$ content of the source rocks. However, $\mathrm{U}$ is generally thought to be quantitatively removed ( 98\%) from seawater during hydrothermal circulation through the oceanic crust (Michard and Albarede, 1985; Chen et al., 1986b). Consequently, the seafloor end-member hydrothermal fluids are depleted in $U$. Therefore, hydrothermal contributions of $U$ to the silica chimneys was likely negligible. The measured $\delta^{234} U$ in the studied silica chimney (close to 
$\delta^{234} U_{\text {seawater; }}$ Table 2) further suggests that seawater was the major source of $U$ in this chimney. Slightly increased $\delta^{234} U$ values in respect to that of seawater (Table 2) imply that there might have been some preferential leaching of ${ }^{234} \mathrm{U}$ from the host basalts, as assumed earlier for the seafloor hydrothermal systems (Chen et al., 1986b), with subsequent coprecipitation or scavenging during chimney formation. If this assumption is correct, then according to our measurements, the proportion of preferentially leached and co-precipitated ${ }^{234} \mathrm{U}$ had gradually decreased in the course of chimney formation (precipitation of layers \#ND 16-08-5 through \#ND 16-08-1, $\delta^{234} U$ in Table 2).

Using the estimated proportions of seawater/end-member hydrothermal fluid in the vent fluid from which the silica chimney precipitated (sub-section 5.4), and assuming their $\mathrm{U}$ concentrations were similar to those of the Pacific deep-seawater and end-member hydrothermal fluids at the EPR $21^{\circ} \mathrm{N}[3.22 \mathrm{ppb}$ and $0.102 \mathrm{ppb}$ (mean), respectively; Chen et al. (1986b)], we can estimate $U$ concentrations in the vent fluid throughout the history of the chimney. It appears that they varied through time [3.03, 2.97, 2.91, 2.75 and $2.97 \mathrm{ppb}$ in the fluid depositing the layers from the oldest (\#ND 16-08-5) to the youngest (\#ND 16-08-1)]. The lack of correlation between calculated $U$ concentrations in the vent fluid and measured $U$ concentrations in the chimney (Table 1) suggests that a factor other than the source fluid composition controlled $U$ deposition in the silica chimney. An increase of four orders of magnitude in the $U$ content of the chimney relative to that of the source fluid implies a very effective mechanism of $U$ uptake.

Mills et al. (1994) suggested that U enrichment within the TAG metalliferous sediments is microbially mediated, based on their own investigations and the proven ability of microorganisms to concentrate $U$ from solution (Lovley et al., 1991). Since the studied silica chimney is likely composed of mineralized bacterial filaments, we propose that its elevated $U$ content (relative to both deep-sea sediments, other silica chimneys, and some metalliferous sediments) is the result of bacterial concentration of $U$ from the seawater-dominated vent fluid. X-ray mapping of thin sections spanning the chimney wall showed that $U$ is most likely concentrated in the yellowish thread-like axial zone (composed of silica and $\mathrm{Fe}$ oxyhydroxides) of the bacterial-like silica filaments (Fig. 4C). This axial zone is interpreted to be the first silica+Fe-oxyhydroxide coating of the bacterial cell. Uranium obviously remained within this silica+Fe-oxyhydroxide coating (Fig. 4C). Further, the bacterial decay and leaching of organic matter (Fig. 3C) may erase the theoretical correlation between the $U$ and organic matter (TOC as indicator) concentrations (Table 1). 


\subsubsection{Rare earth elements}

As mentioned at the beginning of this sub-section (5.5) the concentrations of elements in the silica chimney are a function of both the composition and mixing proportions of the two source fluids: end-member hydrothermal fluid and seawater. Thus, the concentrations of REE in the chimney layers may be expressed as:

$[\mathrm{REE}]_{\mathrm{SC}}=\left([\mathrm{REE}]_{\mathrm{EMHF}} * \%_{\mathrm{EMHF}}\right) / 100+\left([\mathrm{REE}]_{\mathrm{SW}} * \%_{\mathrm{SW}}\right) / 100$, where $[R E E]_{\mathrm{SC}}$ is the concentration of REE in the silica chimney sample, $[\mathrm{REE}]_{\mathrm{EMHF}}$ is the concentration of the same REE in the end-member hydrothermal fluid, \% $\%_{\mathrm{EMHF}}$ is the proportion (in \%) of end-member hydrothermal fluid in the venting fluid from which the sample precipitated, $[\mathrm{REE}]_{\mathrm{SW}}$ is the concentration of the same REE in seawater, and $\%_{\mathrm{SW}}$ is the proportion (in \%) of seawater in the venting fluid. We assume that minimal REE fractionation occurs between the silica precipitate and coeval fluid, as indicated for both modern marine hydrothermal precipitates (Sherrell et al., 1999) and generally assumed for ancient ones (Danielson et al., 1992; Bau and Möller, 1993; Planavsky et al., 2010).

Using this simple equation, the SW:EMHF proportions calculated using Sr-isotope data, the measured REE concentrations of the silica chimney, and the REE concentrations of North Pacific Deep Water [NPDW; Alibo and Nozaki (1999)] as representative of the deep-seawater REE concentrations at the studied site [available REE data for local deep-seawater (Klinkhammer et al., 1983) do not cover the entire REE spectrum], we estimated REE concentrations in the parent end-member hydrothermal fluid. The calculated REE concentrations were used for reconstruction of the REE distribution patterns of the endmember hydrothermal fluids from which the silica chimney layers precipitated (Fig. 6B). Comparison of these patterns (Fig. 6B) with those of the silica chimney samples (Fig. 6A) reveals they are similar, and suggesting that: (1) the silica chimney layers inherited their REE distribution patterns from the parent end-member hydrothermal fluids; (2) dilution of the endmember hydrothermal fluid to $85-94 \%$ seawater could not obliterate the particular features of the REE distribution patterns of the hydrothermal fluids.

The low REE concentrations in the silica chimney ( $\Sigma$ REE $<1 \mathrm{ppm}$; Table 1) are likely due to the high proportion (>85\%) of seawater [with low REE concentrations; Alibo and Nozaki (1999)] diluting the end-member hydrothermal fluid. Substantial dilution of the hydrothermal fluid with seawater resulted in an order of magnitude decrease in the REE concentrations of the silica chimney relative to the parent fluid (Fig. 6). The general decrease in REE concentrations from the oldest (\#ND 16-08-5) to the youngest (\#ND 16-08-1) 
chimney layer (Table 1) is thus more likely controlled by the REE concentrations of the parent hydrothermal fluid (Fig. 6) than the mixing proportions SW:EMHF.

We are aware of only one seafloor silica chimney for which REE data are reported (Sun et al., 2012). The REE concentrations in that chimney are one-two orders of magnitude higher than those of the silica chimney we studied (Table 3). The most remarkable feature of the REE composition of the silica chimney investigated by Sun et al. (2012) is the very high positive Eu anomaly: $\mathrm{Eu} / \mathrm{Eu}^{*}=39.7$. Equally interesting is the high $\mathrm{Ba}$ concentration, which is four orders of magnitude higher than that of the chimney we studied (Table 3). It is well documented (e.g., Greaves et al., 1989) that Ba may produce important isobaric interferences on $\mathrm{Eu}\left({ }^{135} \mathrm{Ba}^{16} \mathrm{O}^{+}\right.$and ${ }^{137} \mathrm{Ba}^{16} \mathrm{O}^{+}$on masses ${ }^{151} \mathrm{Eu}$ and ${ }^{153} \mathrm{Eu}$, respectively) during REE analysis by ICP-MS. Formation rates of $\mathrm{BaO}^{+}$in the plasma during ICP-MS analysis need to be monitored and controlled, and for Ba-rich samples, Ba should be removed by column chromatographic separation (e.g., Barrat et al., 1996). Sun et al. (2012) did not report any such analytical precautions during their REE concentration measurements, and we suggest caution when considering the magnitude of positive Eu anomalies in silica chimneys.

\section{Summary}

The inactive hydrothermal chimney examined herein is composed almost entirely of silica (opal-A)-mineralized bacterial-like filaments. The filaments are supposed to be the result of microbial templating of silica (and Fe-oxyhydroxide) precipitation. U-Th dating of the different concentric layers of the chimney suggests that the chimney grew inwards from the most external layer towards the central chimney conduit. This eventually led to complete sealing of the conduit and cessation of the hydrothermal fluid flow. Mixing between a hypothetical end-member hydrothermal fluid and seawater explains the $\mathrm{Sr}-\mathrm{Nd}$ isotopic composition of the chimney. Seawater was the major source of $\mathrm{Sr}$, whereas the dominant $\mathrm{Nd}$ source was local MORB. The mixing scenarios examined here point to a dynamic system with variable hydrothermal fluid composition. Seawater proportions within the venting fluid responsible for the precipitation of the silica chimney layers varied between 94 and $85 \%$. $\mathrm{Pb}$ isotope data indicates that all of the $\mathrm{Pb}$ in the chimney was derived from the underlying MORB. The fluid venting from the chimney during its lifetime was low-temperature (55$71^{\circ} \mathrm{C}$ ). The temperatures of precipitation of the chimney layers were a function of the seawater/end-member hydrothermal fluid mixing ratio. $\delta^{30} \mathrm{Si}$ correlates with the temperature of precipitation suggesting that temperature is one of the major controls of $\mathrm{Si}$-isotope 
composition of the chimney. Concentrations of elements across the chimney wall were a function of both the mixing proportions of the two source fluids (seawater and hydrothermal fluid) and the composition of the hydrothermal fluid. The inward growth of the chimney wall and accompanying decrease in wall permeability resulted in an inward decrease in the seawater/hydrothermal fluid mixing ratio, which in turn exerted a control on the concentrations of the elements that were supplied mostly by the hydrothermal fluids. This silica chimney is significantly enriched in $U$, perhaps as the result of bacterial concentration of $U$ from the seawater-dominated vent fluid. The chimney is poor in REE. It inherited its REE distribution patterns from the parent end-member hydrothermal fluids, and dilution of the hydrothermal fluid with over $85 \%$ of seawater could not obliterate the particular features (e.g., positive Eu anomaly) of the REE distribution patterns of the hydrothermal fluids.

\section{Acknowledgements}

This research was supported by a Marie Curie Intra European Fellowship (7th European Community Framework Programme; grant \#253182, IsoBAB) to V. M. Dekov. S. Lalonde acknowledges support from LabexMER.

\section{References}

Abraham, K., Opfergelt, S., Fripiat, F., Cavagna, A.-J., De Jong, J.T.M., Foley, S.F., André, L., Cardinal, D., 2008. $\delta^{30} \mathrm{Si}$ and $\delta^{29} \mathrm{Si}$ determinations on USGS BHVO-1 and BHVO-2 reference materials with a new configuration on a Nu Plasma multi-collector ICP-MS. Geostandards and Geoanalytical Research 32, 193202.

Alibo, D.S., Nozaki, Y., 1999. Rare earth elements in seawater: particle association, shale-normalization, and Ce oxidation. Geochim. Cosmochim. Acta 63, 363-372.

Anderson, D.L., 1989. Composition of the Earth. Science 243, 367-370.

Armytage, R.M.G., Georg, R.B., Savage, P.S., Williams, H.M., Halliday, A.N., 2011. Silicon isotopes in meteorites and planetary core formation. Geochim. Cosmochim. Acta 75, 3662-3676.

Auzende, J.-M., Ballu, V., Batiza, R., Bideau, D., Cormier, M.-H., Fouquet, Y., Geistdoerfer, P., Lagabrielle, Y., Sinton, J., Spadea, P., 1994a. Activité magmatique, tectonique et hydrothermale actuelle sur la Dorsale Est Pacifique entre $17^{\circ}$ et $19^{\circ} \mathrm{S}$ (campagne NAUDUR). C. R. Acad. Sci. Paris série II, 319, 811-818.

Auzende, J.-M., Sinton, J., and Scientific Party, 1994b. NAUDUR explorers discover recent volcanic activity along the East Pacific Rise. Eos, Trans. Amer. Geophys. Union 75, 601, 604-605.

Auzende, J.-M., Ballu, V., Batiza, R., Bideau, D., Charlou, J.-L., Cormier, M.-H., Fouquet, Y., Geistdoerfer, P., Lagabrielle, Y., Sinton, J., Spadea, P., 1996. Recent tectonic, magmatic, and hydrothermal activity on the 
East Pacific Rise between $17^{\circ} \mathrm{S}$ and $19^{\circ} \mathrm{S}$ : Submersible observations. J. Geophys. Res. 101, B8, 1799518010.

Bäcker, H., Lange, J., Marchig, V., 1985. Hydrothermal activity and sulfide formation in axial valleys of the East Pacific Rise crest between $18^{\circ}$ and $22^{\circ}$ S. Earth Planet. Sci. Lett. 72, 9-22.

Baross, J.A., Deming, J.W., 1985. The role of bacteria in the ecology of black smoker environments. Bulletin of the Biological Society of Washington 6, 355-371.

Barrat, J.-A., Keller, F., Amossé, J., Taylor, R.N., Nesbitt, R.W., Hirata, T., 1996. Determination of rare earth elements in sixteen silicate reference samples by ICP-MS after Tm addition and ion exchange separation. Geostand. Newslett. 20, 133-139.

Basile-Doelsch, I., 2006. Si stable isotopes in the Earth's surface. A review. J. Geochem. Explor. 88, 252-256.

Baturin, G.N., 2011. Geochemistry of sapropel in the Black Sea. Geochem. Int.+ 49, 531-535.

Bau, M., Möller, P., 1993. Rare earth element systematics of the chemically precipitated component in Early Precambrian iron formations and the evolution of the terrestrial atmosphere-hydrosphere-lithosphere system. Geochim. Cosmochim. Acta 57, 2239-2249.

Bayon, G., Barrat, J.-A., Etoubleau, J., Benoit, M., Bollinger, C., Révillon, S., 2009a. Determination of rare earth elements, Sc, Y, Zr, Ba, Hf and Th in geological samples by ICP-MS after Tm addition and alkaline fusion. Geostand. Geoanal. Res. 33, 51-62.

Bayon, G., Henderson, G.M., Bohn, M., 2009b. U-Th stratigraphy of a cold seep carbonate crust. Chem. Geol. $260,47-56$.

Bergmanis, E.C., Sinton, J., Rubin, K.H., 2007. Recent eruptive history and magma reservoir dynamics on the southern East Pacific Rise at 17³0'S. Geochem. Geophys. Geosys. 8, doi:10.1029/2007GC001742.

Charlou, J.L., Fouquet, Y., Donval, J.P., Auzende, J.M., 1996. Mineral and gas chemistry of hydrothermal fluids on an ultrafast spreading ridge: East Pacific Rise, $17^{\circ}$ to $19^{\circ} \mathrm{S}$ (Naudur cruise, 1993) phase separation processes controlled by volcanic and tectonic activity. J. Geophys. Res. 101, 15899-15919.

Chen, D., Wang, J., Qing, H., Yan, D., Li, R., 2009. Hydrothermal venting activities in the Early Cambrian, South China: Petrological, geochronological and stable isotopic constraints. Chem. Geol. 258, 168-181.

Chen, J.H., Edwards, R.L., Wasserburg, G.J., 1986a. ${ }^{238}$ U, ${ }^{234} \mathrm{U}$ and ${ }^{232}$ Th in seawater. Earth Planet. Sci. Lett. 80, 241-251.

Chen, J.H., Wasserburg, G.J., Von Damm, K.L., Edmond, J.M., 1986b. The U-Th-Pb systematics in hot springs on the East Pacific Rise at $21^{\circ} \mathrm{N}$ and in the Guaymas Basin. Geochim. Cosmochim. Acta 50, 2467-2479.

Clayton, R.N., Mayeda, T.K., 1963. The use of bromine pentafluoride in the extraction of oxygen from oxides and silicates for isotopic analysis. Geochim. Cosmochim. Acta 27, 43-52.

Clayton, R.N., O'Neil, J.R., Mayeda, T.K., 1972. Oxygen isotope exchange between quartz and water. J. Geophys. Res. 77, 3057-3066.

Cormier, M.H., Macdonald, K.C., 1994. East Pacific Rise $18^{\circ}-19^{\circ} \mathrm{S}$ asymmetric spreading and ridge reorientation by ultra-fast migration of axial discontinuities. J. Geophys. Res. 99, 543-564.

Cowen, J.P., Shackelford, R., McGee, D., Baker, E.T., Lam, P., Olson, E.J., 1999. Microbial biomass in the hydrothermal plumes associated with the 1998 Axial Volcano eruption. Geophys. Res. Lett. 26, 3637-3640.

Danielson, A., Möller, P., Dulski, P., 1992. The europium anomalies in banded iron formations and the thermal history of the oceanic crust. Chem. Geol. 97, 89-100. 
Davis, R.E., Stakes, D.S., Wheat, C.G., Moyer, C.L., 2009. Bacterial variability within an iron-silica-manganeserich hydrothermal mound located off-axis at the Cleft Segment, Juan de Fuca Ridge. Geomicrobiology Journal 26, 570-580.

De La Rocha, C.L., Brzezinski, M.A., DeNiro, M.J., 1997. Fractionation of silicon isotopes by marine diatoms during biogenic silica formation. Geochim. Cosmochim. Acta 61, 5051-5056.

De La Rocha, C.L., Brzezinski, M.A., DeNiro, M.J., 2000. A first look at the distribution of the stable isotopes of silicon in natural waters. Geochim. Cosmochim. Acta 64, 2467-2477.

de Souza, G.F., Reynolds, B.C., Rickli, J., Frank, M., Saito, M.A., Gerringa, L.J.A., Bourdon, B., 2012. Southern Ocean control of silicon stable isotope distribution in the deep Atlantic Ocean. Global Biogeochem. Cy. 26, GB2035.

DeMets, C., Gordon, R.G., Argus, D.F., Stein, S., 1990. Current plate motions. Geophys. J. Int. 101, 425-478.

Douville, E., Bienvenu, P., Charlou, J.L., Donval, J.P., Fouquet, Y., Appriou, P., Gamo, T., 1999. Yttrium and rare earth elements in fluids from various deep-sea hydrothermal systems. Geochim. Cosmochim. Acta 63, 627-643.

Fein, J.B., Scott, S., Rivera, N., 2002. The effect of Fe on Si adsorption by Bacillus subtilis cell walls: insights into non-metabolic bacterial precipitation of silicate minerals. Chem. Geol. 182, 265-273.

Fisher, D.E., Boström, K., 1969. Uranium rich sediments on the East Pacific Rise. Nature 224, 64-65.

Fortin, D., Ferris, F.G., Scott, S.D., 1998. Formation of Fe-silicates and Fe-oxides on bacterial surfaces in samples collected near hydrothermal vents on the Southern Explorer Ridge in the northeast Pacific Ocean. Am. Mineral. 83, 1399-1408.

Fouquet, Y., Auzende, J.-M., Ballu, V., Batiza, R., Bideau, D., Cormier, M.-H., Geistdoerfer, P., Lagabrielle, Y., Sinton, J., Spadea, P., 1994. Variabilité des manifestations hydrothermales actuelles le long d'une dorsale ultra-rapide: Exemple de la Dorsale Est Pacifique entre $17^{\circ}$ et $19^{\circ} \mathrm{S}$ (campagne NAUDUR). C. R. Acad. Sci. Paris série II, 319, 1399-1406.

Fouquet, Y., Marcoux, E., 1995. Lead isotope systematics in Pacific hydrothermal sulfide deposits. J. Geophys. Res. 100, B4, 6025-6040.

Fouquet, Y., Cambon, P., Etoubleau, J., Charlou, J.L., Ondréas, H., Barriga, F.J.A.S., Cherkashov, G., Semkova, T., Poroshina, I., Bohn, M., Donval, J.P., Henry, K., Murphy, P., Rouxel, O., 2010. Geodiversity of hydrothermal processes along the Mid-Atlantic Ridge and ultramafic-hosted mineralization: A new type of oceanic Cu-Zn-Co-Au volcanogenic massive sulfide deposit. In: Rona, P.A., Devey, C.W., Dyment, J., Murton, B.J. (Eds.), Diversity of Hydrothermal Systems on Slow Spreading Ocean Ridges. Geophysical Monograph 188, 321-367.

Frank, M., 2002. Radiogenic isotopes: tracers of past ocean circulation and erosional input. Reviews in Geophysics 40, 1-38.

García-Ruiz, J.M., Hyde, S.T., Carnerup, A.M., Christy, A.G., Van Kranendonk, M.J., Welham, N.J., 2003. Selfassembled silica-carbonate structures and detection of ancient microfossils. Science 302, 1194-1197.

Geilert, S., Vroon, P.Z., Roerdink, D.L., Van Cappellen, P., van Bergen, M.J., 2014. Silicon isotope fractionation during abiotic silica precipitation at low temperatures: Inferences from flow-through experiments. Geochim. Cosmochim. Acta 142, 95-114. 
Geilert, S., Vroon, P.Z., Keller, N.S., Gudbrandsson, S., Stefánsson, A., van Bergen, M.J., 2015. Silicon isotope fractionation during silica precipitation from hot-spring waters: Evidence from the Geysir geothermal field, Iceland. Geochim. Cosmochim. Acta 164, 403-427.

Georg, R.B., Reynolds, B.C., Frank, M., Halliday, A.N., 2006. New sample preparation techniques for the determination of Si isotopic compositions using MC-ICPMS. Chem. Geol. 235, 95-104.

German, C.R., Von Damm, K.L., 2006. Hydrothermal processes. In: Elderfield, H. (Ed.), The Oceans and Marine Geochemistry. Treatise on Geochemistry vol. 6, pp. 181-222.

Glazer, B.T., Rouxel, O.J., 2009. Redox speciation and distribution within diverse iron-dominated microbial habitats at Loihi Seamount. Geomicrobiology Journal 26, 606-622.

Gonfiantini, R., 1978. Standards for stable isotope measurements in natural compounds. Nature 271, 534-536.

Greaves, M.J., Elderfield, H., Klinkhammer, G.P., 1989. Determination of the rare earth elements in natural waters by isotope-dilution mass spectrometry. Anal. Chim. Acta 218, 265-280.

Gurvich, E.G., 2006. Metalliferous Sediments of World Ocean. Fundamental Theory of Deep-Sea Hydrothermal Sedimentation. Springer, Heidelberg, p. 420.

Hein, J.R., Clague, D.A., Koski, R.A., Embley, R.W., Dunham, R.E., 2008. Metalliferous sediment and a silicahematite deposit within the Blanco Fracture Zone, Northeast Pacific. Mar. Georesour. Geotec. 26, 317-339.

Hékinian, R., 1982. Petrology of the Ocean Floor. Elsevier, Amsterdam, p. 389.

Herzig, P.M., Becker, K.P., Stoffers, P., Bäcker, H., Blum, N., 1988. Hydrothermal silica chimney fields in the Galapagos Spreading Center at $86^{\circ}$ W. Earth Planet. Sci. Lett. 89, 261-272.

Hughes, H.J., Delvigne, C., Korntheuer, M., de Jong, J., André, L., Cardinal, D., 2011. Controlling the mass bias introduced by anionic and organic matrices in silicon isotopic measurements by MC-ICP-MS. J. Anal. At. Spectrom. 26, 1892-1896.

Jaeschke, A., Eickmann, B., Lang, S.Q., Bernasconi, S.M., Strauss, H., Früh-Green, G.L., 2014. Biosignatures in chimney structures and sediment from the Loki's Castle low-temperature hydrothermal vent field at the Arctic Mid-Ocean Ridge. Extremophiles 18, 545-560.

Jannasch, H.W., Wirsen, C.O., 1981. Morphological survey of microbial mats near deep-sea thermal vents. Appl. Environ. Microbiol. 41, 528-538.

Jiang, S.-Y., Palmer, M.R., Ding, T.-P., Wan, D.-F., 1994. Silicon isotope geochemistry of the Sullivan Pb-Zn deposit, Canada: A preliminary study. Econ. Geol. 89, 1623-1629.

Jonasson, I.R., Perfit, M.R., 1999. Unusual forms of amorphous silica from submarine warm springs, Juan de Fuca Ridge, northeastern Pacific Ocean. Can. Mineral. 37, 27-36.

Jones, B., Konhauser, K.O., Renaut, R.W., Wheeler, R.S., 2004. Microbial silicification in Iodine Pool, Waimangu geothermal area, North Island, New Zealand: implications for recognition and identification of ancient silicified microbes. J. Geol. Soc. 161, 983-993.

Juniper, S.K., Fouquet, Y., 1988. Filamentous iron-silica deposits from modern and ancient hydrothermal sites. Can. Mineral. 26, 859-869.

Juniper, S.K., Bird, D.F., Summit, M., Vong, M.P., Baker, E.T., 1998. Bacterial and viral abundances in hydrothermal event plumes over northern Gorda Ridge. Deep-Sea Research II, 45, 2739-2749. 
Kamenov, G.D., Perfit, M.R., Mueller, P.A., Jonasson, I.R., 2008. Controls on magmatism in an island arc environment: study of lavas and sub-arc xenoliths from the Tabar-Lihir-Tanga-Feni island chain, Papua New Guinea. Contrib. Mineral. Petr. 155, 635-656.

Karl, D.M., 1995. Ecology of free-living, hydrothermal vent microbial communities. In: Karl, D.M. (Ed.), The Microbiology of Deep-Sea Hydrothermal Vents. CRC Press, N.Y., pp. 219-253.

Klinkhammer, G., Elderfield, H., Hudson, A., 1983. Rare earth elements in seawater near hydrothermal vents. Nature 305, 185-188.

Kuznetsov, V., Maksimov, F., Zheleznov, A., Cherkashov, G., Bel’tenev, V., Lazareva, L., 2011. ${ }^{230} \mathrm{Th} / \mathrm{U}$ chronology of ore formation within the Semyenov hydrothermal district $\left(13^{\circ} 31^{\prime} \mathrm{N}\right)$ at the Mid-Atlantic Ridge. Geochronometria 38, 72-76.

Lalonde, S.V., Konhauser, K.O., Reysenbach, A.-L., Ferris, F.G., 2005. The experimental silicification of Aquificales and their role in hot spring sinter formation. Geobiology 3, 41-52.

Lalou, C., Brichet, E., Lange, J., 1989. Fossil hydrothermal sulfide deposits at the Galapagos Spreading Centre near $85^{\circ} 00$ West: geological setting, mineralogy and chronology. Oceanologica Acta 12, 1-8.

Lalou, C., Reyss, J.-L., Brichet, E., Rona, P.A., Thompson, G., 1995. Hydrothermal activity on a $10^{5}$-year scale at a slow-spreading ridge, TAG hydrothermal field, Mid-Atlantic Ridge $26^{\circ}$ N. J. Geophys. Res. 100, B9, 17855-17862.

Li, J., Zhou, H., Peng, X., Wu, Z., Chen, S., Fang, J., 2012. Microbial diversity and biomineralization in lowtemperature hydrothermal iron-silica-rich precipitates of the Lau Basin hydrothermal field. FEMS Microbiol. Ecol. 81, 205-216.

Lonsdale, P., 1989. Segmentation of the Pacific-Nazca spreading center, $1^{\circ}$ N-20 ${ }^{\circ}$ S. J. Geophys. Res. 94, $12197-$ 12226.

Lovley, D.R., Phillips, E.J.P., Gorby, Y.A., Landa, E.R., 1991. Microbial reduction of uranium. Nature 350, 413416.

Macdonald, K.C., Fox, P.J., 1988. The axial summit graben and cross-sectional shape of the East Pacific Rise as indicators of axial magma chambers and recent volcanic eruptions. Earth Planet. Sci. Lett. 88, 119-131.

Macdonald, K.C., Haymon, R.M., Miller, S.P., Sempere, J.C., Fox, P.J., 1988. Deep-tow and Sea Beam studies of dueling propagating ridges on the East Pacific Rise near 2040'S. J. Geophys. Res. 93, 2875-2898.

Mangini, A., Dominik, J., 1979. Late Quaternary sapropel on the Mediterranean Ridge: U-budget and evidence for low sedimentation rates. Sediment. Geol. 23, 113-125.

Michard, A., Albarède, F., 1985. Hydrothermal uranium uptake at ridge crests. Nature 317, 244-246.

Mills, R.A., Thomson, J., Elderfield, H., Hinton, R.W., Hyslop, E., 1994. Uranium enrichment in metalliferous sediments from the Mid-Atlantic Ridge. Earth Planet. Sci. Lett. 124, 35-47.

Miyoshi, N., Yamaguchi, Y., Makino, K., 2005. Successive zoning of Al and H in hydrothermal vein quartz. Am. Mineral. 90, 310-315.

Naar, D.F., Hey, R.N., 1989. Recent Pacific-Easter-Nazca plate motions. In: Sinton, J.M. (Ed.), Evolution of Mid-Ocean Ridges. Geophys. Monogr. 57, AGU, Washington, D.C., 9-30.

Oelze, M., von Blanckenburg, F., Hoellen, D., Dietzel, M., Bouchez, J., 2014. Si stable isotope fractionation during adsorption and the competition between kinetic and equilibrium isotope fractionation: Implications for weathering systems. Chem. Geol. 380, 161-171. 
Perram, L.J., Cormier, M.H., Macdonald, K.C., 1993. Magnetic and tectonic studies of the dueling propagating spreading centers at $20^{\circ} 40^{\prime} \mathrm{S}$ on the East Pacific Rise: Evidence for crustal rotations. J. Geophys. Res. 98, 13850-13885.

Phoenix, V.R., Konhauser, K.O., Ferris, F.G.., 2003. Experimental study of iron and silica immobilization by bacteria in mixed Fe-Si systems: Implications for microbial silicification in hot-springs. Canadian Journal of Earth Sciences 40, 1669-1678.

Planavsky, N., Bekker, A., Rouxel, O.J., Kamber, B., Hofmann, A., Knudsen, A., Lyons, T.W., 2010. Rare earth element and yttrium compositions of Archean and Paleoproterozoic Fe formations revisited: New perspectives on the significance and mechanisms of deposition. Geochim. Cosmochim. Acta 74, 6387-6405.

Robinson, L.F., Belshaw, N.S., Henderson, G.M., 2004. U and Th concentrations and isotope ratios in modern carbonates and waters from the Bahamas. Geochim. Cosmochim. Acta 68, 1777-1789.

Scheirer, D.S., Macdonald, K.C., Forsyth, D.W., 1993. Widespread volcanic and tectonic activity on the southern East Pacific Rise and its flanks. RIDGE Events 4, 8-10.

Scott, M.R., Salter, P.F., Barnard, L.A., 1979. Chemistry of ridge-crest sediments from the North Atlantic Ocean. In: Talwani, M., Harrison, C.G., Hayes, D.E. (Eds), Deep Drilling Results in the Atlantic Ocean: Ocean Crust. American Geophysical Union, Washington, D. C., pp. 403-428.

Shanks, W.C., III, 2001. Stable isotopes in seafloor hydrothermal systems: Vent fluids, hydrothermal deposits, hydrothermal alteration, and microbial processes. In: Valley, J.W. and Cole, D.R. (Eds.), Stable Isotope Geochemistry, Reviews in Mineralogy and Geochemistry, Mineralogical Society of America, 43, Washington, D.C., p. 469-526.

Shanks, W.C., III, Morgan, L.A., Balistrieri, L., Alt, J., 2005. Hydrothermal vent fluids, siliceous hydrothermal deposits, and hydrothermally altered sediments in Yellowstone Lake. In: Inskeep, W.P., McDermott, T.R. (Eds), Geothermal Biology and Geochemistry in Yellowstone National Park. Proceedings of the Thermal Biology Institute workshop, Yellowstone National Park, October 2003. Montana State University Press, Bozeman, MT, 53-72.

Sherrell, R.M., Field, M.P., Ravizza, G., 1999. Uptake and fractionation of rare earth elements on hydrothermal plume particles at $9^{\circ} 45^{\prime} \mathrm{N}$, East Pacific Rise. Geochim. Cosmochim. Acta 63, 1709-1722.

Sinton, J.M., Smaglik, S.M., Mahoney, J.J., Macdonald, K.C., 1991. Magmatic processes at superfast spreading mid-ocean ridges: Glass compositional variations along the East Pacific Rise $13^{\circ}-23^{\circ} \mathrm{S}$. J. Geophys. Res. 96 , 6133-6155.

Stüben, D., Taibi, N.E., McMurtry, G.M., Scholten, J., Stoffers, P., Zhang, D., 1994. Growth history of a hydrothermal silica chimney from the Mariana backarc spreading center (southwest Pacific, $18^{\circ} 13^{\prime} \mathrm{N}$ ). Chem. Geol. 113, 273-296.

Sudek, L.A., Templeton, A.S., Tebo, B.M., Staudigel, H., 2009. Microbial ecology of Fe (hydr)oxide mats and basaltic rock from Vailulu'u Seamount, American Samoa. Geomicrobiology Journal 26, 581-596.

Sun, S.-S., McDonough, W.F., 1989. Chemical and isotopic systematics of oceanic basalts: implications for mantle composition and processes. In: Saunders, A.D., Norry, M.J. (Eds.), Magmatism in the Ocean Basins. Geological Society of London, Special Publications, 42, 313-345. 
Sun, Z.L., Zhou, H.Y., Yang, Q.H., Yin, X.J., Wang, H., Yao, H.Q., Dong, C.F., 2012. Growth model of a hydrothermal low-temperature Si-rich chimney: Example from the CDE hydrothermal field, Lau Basin. Science China, Earth Sciences, 55, 1716-1730.

Takai, K., Nunoura, T., Horikoshi, K., Shibuya, T., Nakamura, K., Suzuki, Y., Stott, M., Massoth, G.J., Christenson, B.W., de Ronde, C.E.J., Butterfield, D.A., Ishibashi, J., Lupton, J.E., Evans, L.J., 2009. Variability in microbial communities in black smoker chimneys at the NW Caldera vent field, Brothers Volcano, Kermadec Arc. Geomicrobiology Journal 26, 552-569.

Ueshima, M., Tazaki, K., 2001. Possible role of microbial polysaccharides in nontronite formation. Clays and Clay Minerals 49, 292-299.

Urabe, T., Kusakabe, M., 1990. Barite silica chimneys from the Sumisu Rift, Izu-Bonin Arc: possible analog to hematitic chert associated with Kuroko deposits. Earth Planet. Sci. Lett. 100, 283-290.

Urrutia, M.M., Beveridge, T.J., 1994. Formation of fine-grained silicate minerals and metal precipitates by a bacterial surface (Bacillus subtilis) and the implications in the global cycling of silicon. Chem. Geol. 116, 261-280.

Veeh, H.H., 1967. Deposition of uranium from the ocean. Earth Planet. Sci. Lett. 3, 145-150.

Weyer, S., Anbar, A.D., Gerdes, A., Gordon, G.W., Algeo, T.J., Boyle, E.A., 2008. Natural fractionation of ${ }^{238} \mathrm{U} /{ }^{235} \mathrm{U}$. Geochim. Cosmochim. Acta 72, 345-359.

Yee, N., Phoenix, V.R., Konhauser, K.O., Benning, L.G., Ferris, F.G., 2003. The effect of cyanobacteria on silica precipitation at neutral $\mathrm{pH}$ : Implications for bacterial silicification in geothermal hot springs. Chem. Geol. 199, 83-90.

Ziegler, K., Chadwick, O.A., Brzezinski, M.A., Kelly, E.F., 2005. Natural variations of $\delta^{30}$ Si ratios during progressive basalt weathering, Hawaiian Islands. Geochim. Cosmochim. Acta 69, 4597-4610. 
Figure captions

Fig. 1. (A) Schematic tectonic map of the south east Pacific Ocean showing the location of the studied area (solid rectangle) on the East Pacific Rise between the Garrett Fracture Zone (Garrett F.Z.) and Easter Microplate; (B) bathymetry sketch map (after Auzende et al., 1994) of the studied axial segment of the East Pacific Rise showing the track of the DSV Nautile dive \#16 within the axial valley and observed geological features: $1=$ major normal fault, $2=$ normal fault, $3=$ axial graben, $4=$ pillow lavas, $5=$ lobated lavas, $6=$ inactive hydrothermal site. Location of the studied silica chimney \#ND 16-08 within one of the inactive hydrothermal sites is shown.

Fig. 2. (A) Cluster of inactive silica chimneys in the EPR axial graben at $18^{\circ} 14^{\prime} \mathrm{S}$ with the studied chimney (white rectangle) shown at (B); (B) Spire of the studied inactive silica chimney with position of the cross-section (C-C) shown at (C); (C) cross-section of the studied chimney spire (Fig. 2B) with sample locations (numbers 1 to 5 correspond to samples \#ND 16-08-1 to \#ND 16-08-5).

Fig. 3. Photomicrographs of silica filaments, which compose the inactive chimney \#ND 16-08: (A) general view of the silica filaments (sample \#ND 16-08-1; SEM SEI); (B) twisted ribbon-like silica filaments finely coated with Fe-oxyhydroxides (sample \#ND 16-08-5; SEM SEI); (C) higher magnification image of the silica filaments, note the hollow central part of the broken filaments (close up of A; SEM SEI); (D) coiled silica filaments (sample \#ND 16-08-2; SEM SEI); (E) cross section of silica filaments showing the yellowish thread-like central part (contains $\mathrm{Si}, \mathrm{O}$ and Fe; EDS analysis) enveloped by silica (greyish) (sample \#ND 16-08-1; optical microscope, transmitted plane polarized light, thin polished section); (F) close-up cross section of silica filaments, note the orange-brown fine external coating (Fe and O; EDS studies) of the filaments (sample \#ND 16-08-2; optical microscope, transmitted plane polarized light, thin polished section).

Fig. 4. X-ray maps of longitudinally sectioned silica filaments (sample \#ND 16-08-1; thin polished section): (A) X-ray scan in $\mathrm{Si} K_{\alpha}$; (B) X-ray scan in Fe $K_{\alpha}$; (C) X-ray scan in $\mathrm{U} M_{\alpha}$. Concentrations of Si, Fe and $\mathrm{U}$ on the maps decrease from red to blue; EMP point analyses in different zones are indicated in wt.\%.

Fig. 5. TEM images of ultra-microtome sections across the most external chimney layer (\#ND 16-08-5): (A) tubular structures with an amorphous silica central zone and electron dense Fe-rich outer wall; (B) fine needles or crumpled sheets of Fe-oxyhydroxides scattered among the tubular structures.

Fig. 6. C1 chondrite-normalized (Sun and McDonough, 1989) REE distribution patterns of: (A) silica chimney samples [NPDW = North Pacific Deep Water (Alibo and Nozaki, 1999)]; (B) end-member hydrothermal fluids (EMHF) that deposited silica chimney samples (EMHF-1 is the fluid that deposited sample \#ND 16-08-1, EMHF-3 is the fluid that deposited sample \#ND 16-08-3, etc.).

Fig. 7. Silicon isotope composition of the studied inactive silica chimney compared to that of similar silica deposits [silica sinters at the Icelandic hot springs (Geilert et al., 2015), siliceous sediment at Mariana black 
smoker (Jiang et al., 1994)] and their precipitating fluids [Icelandic hot (67-100 $\left.{ }^{\circ} \mathrm{C}\right)$ springs (Geilert et al., 2015), seafloor hydrothermal fluids at $9^{\circ} \mathrm{N}$ EPR (De La Rocha et al., 2000)]. Si-isotope composition of terrestrial magmatic rocks [light-grey strip, Armytage et al. (2011)] and seawater (De La Rocha et al., 2000) are shown as basic markers.

Fig. 8. Comparison of the silica chimney Sr-Nd-isotope composition with those of the local basalts and seawater. Sr- and Nd-isotope data for the EPR basalts between $15.8^{\circ} \mathrm{S}$ and $18.9^{\circ} \mathrm{S}$ show ${ }^{87} \mathrm{Sr}^{86} \mathrm{Sr}_{\text {average }}=0.70259$ and ${ }^{143} \mathrm{Nd} /{ }^{144} \mathrm{Nd}_{\text {average }}=0.51313$ based on data obtained from PetDB database (http://www.earthchem.org/petdb). Ndisotope data for the local seawater are after Frank (2002) and $\mathrm{Nd}$ concentration of $0.0023 \mathrm{ppb}$ for deep seawater at $19^{\circ} \mathrm{S}$ EPR from Klinkhammer et al. (1983). Solid lines represent mixing curves between seawater $(\mathrm{Sr}=7.6$ ppm and $\left.{ }^{87} \mathrm{Sr} /{ }^{86} \mathrm{Sr}=0.70917\right)$ and four hydrothermal fluids with the same isotopic composition as the local basalts, but variable concentrations of $\mathrm{Sr}$ and $\mathrm{Nd}$ : $\operatorname{mix} \mathrm{A}(\mathrm{Sr}=15 \mathrm{ppm}, \mathrm{Nd}=1.1 \mathrm{ppb}), \operatorname{mix} \mathrm{B}(\mathrm{Sr}=8 \mathrm{ppm}, \mathrm{Nd}=$ $1.1 \mathrm{ppb})$, mix $\mathrm{C}(\mathrm{Sr}=8 \mathrm{ppm}, \mathrm{Nd}=0.11 \mathrm{ppb})$, and mix $\mathrm{D}(\mathrm{Sr}=15 \mathrm{ppm}, \mathrm{Nd}=0.11 \mathrm{ppb})$. Dashed line connects the $90 \%$ seawater component on the mixing curves. Point numbers 1, 2, 3, 4 and 5 correspond to the sample numbers \#ND 16-08-1, -2, -3, -4 and -5, respectively.

Fig. 9. Silica chimney $\mathrm{Pb}$ isotopes compared to $\mathrm{Pb}$ isotope data for EPR basalts between $15.8^{\circ} \mathrm{S}$ and $18.9^{\circ} \mathrm{S}$ [data obtained from PetDB database and Bergmanis et al. (2007)] and EPR sulfide chimneys between $17.26^{\circ} \mathrm{S}$ and $18.31^{\circ} \mathrm{S}$ [data from Fouquet and Marcoux (1995)]. Point numbers 1, 2, 3, 4 and 5 correspond to the sample numbers \#ND 16-08-1, -2, -3, -4 and -5, respectively. Note that the silica chimney samples plot entirely within the field of the local basalts suggesting that all of the $\mathrm{Pb}$ is derived from the underlying volcanic units.

Fig. 10. Variations of the temperature of precipitation of the silica chimney layers (calculated from the $\mathrm{O}$ isotope data), proportions of seawater in the precipitating vent fluid (calculated from the Sr isotope data) and Si isotope composition across the silica chimney wall. 


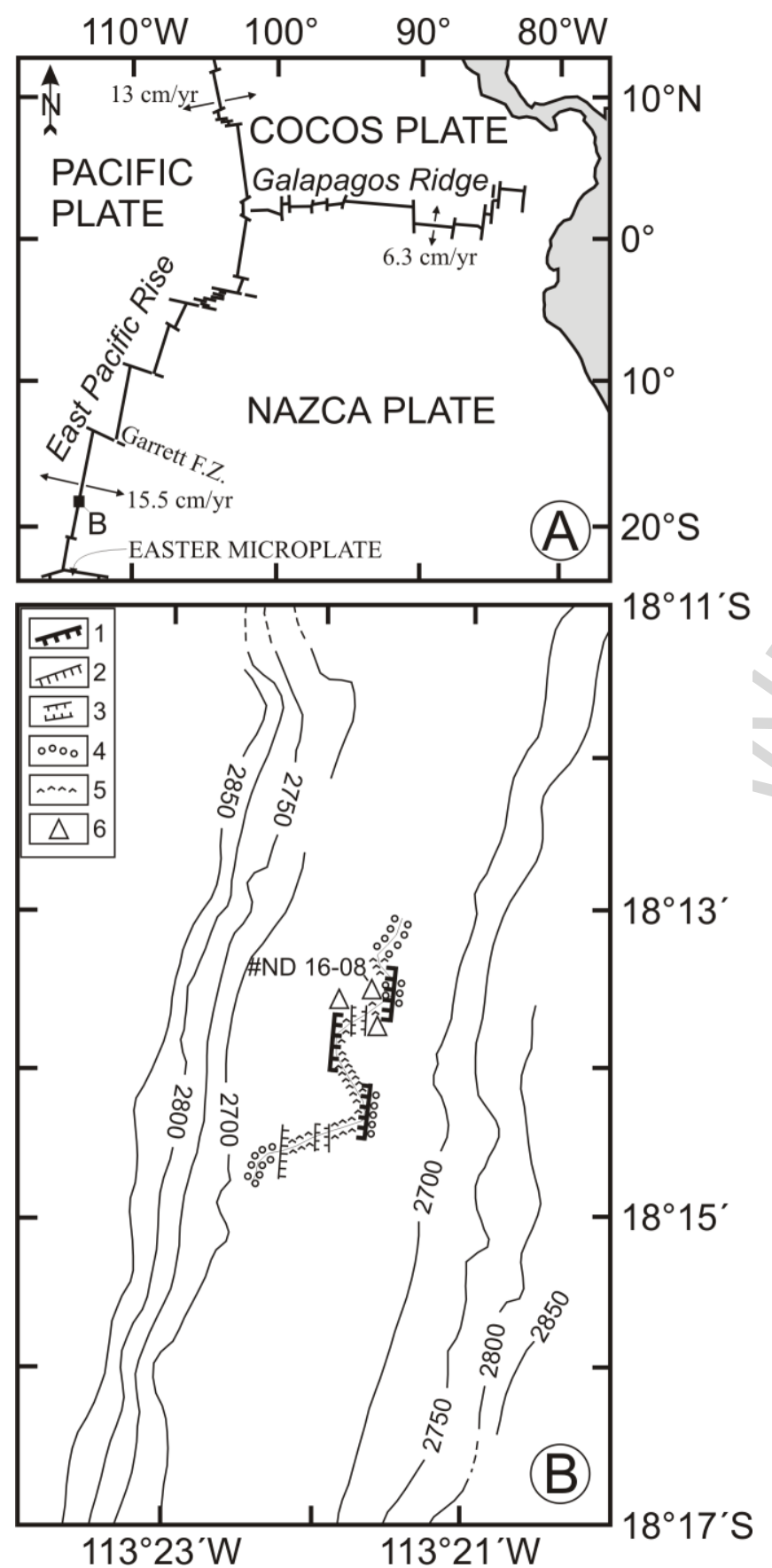

Fig. 1 

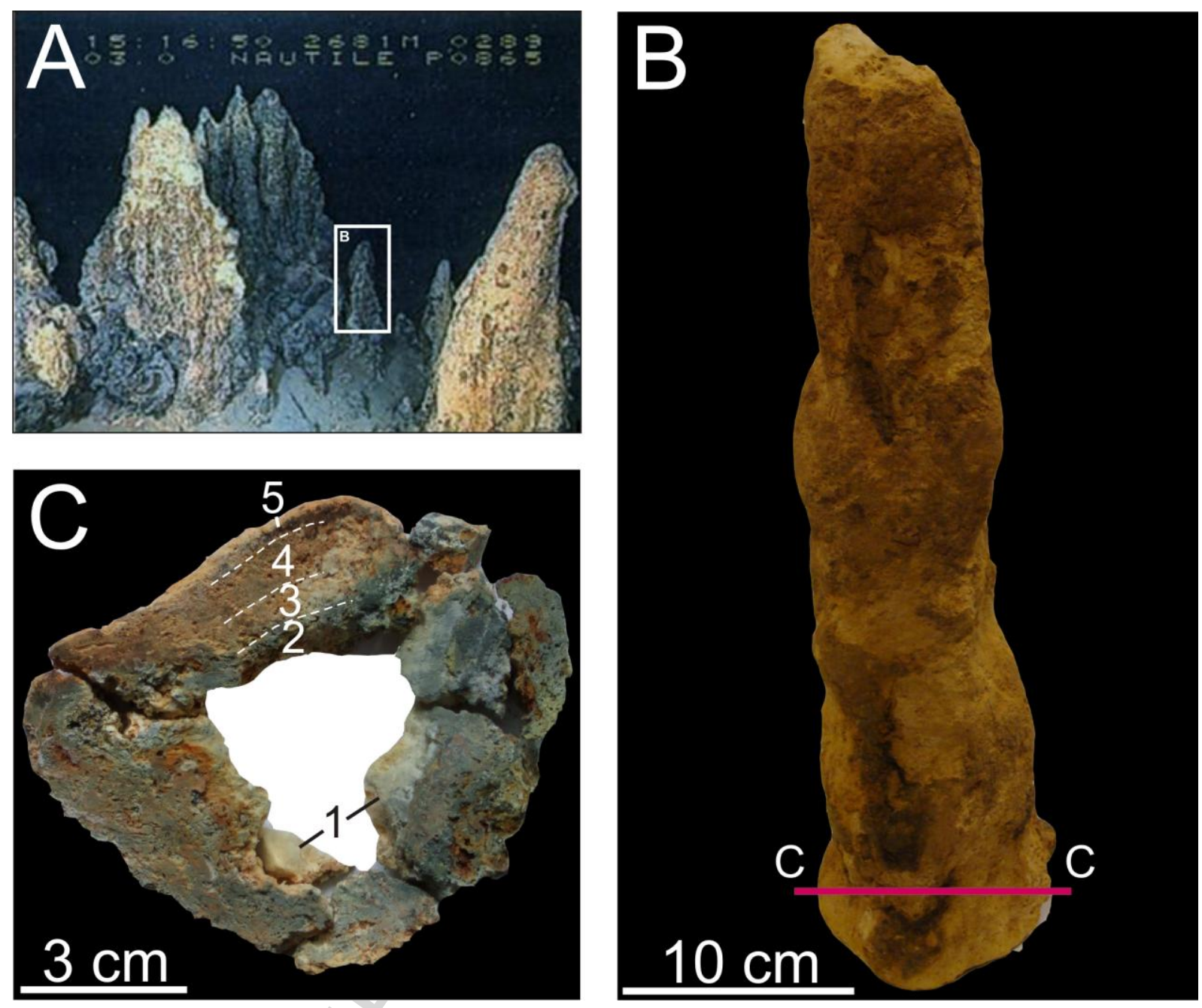

Fig. 2 

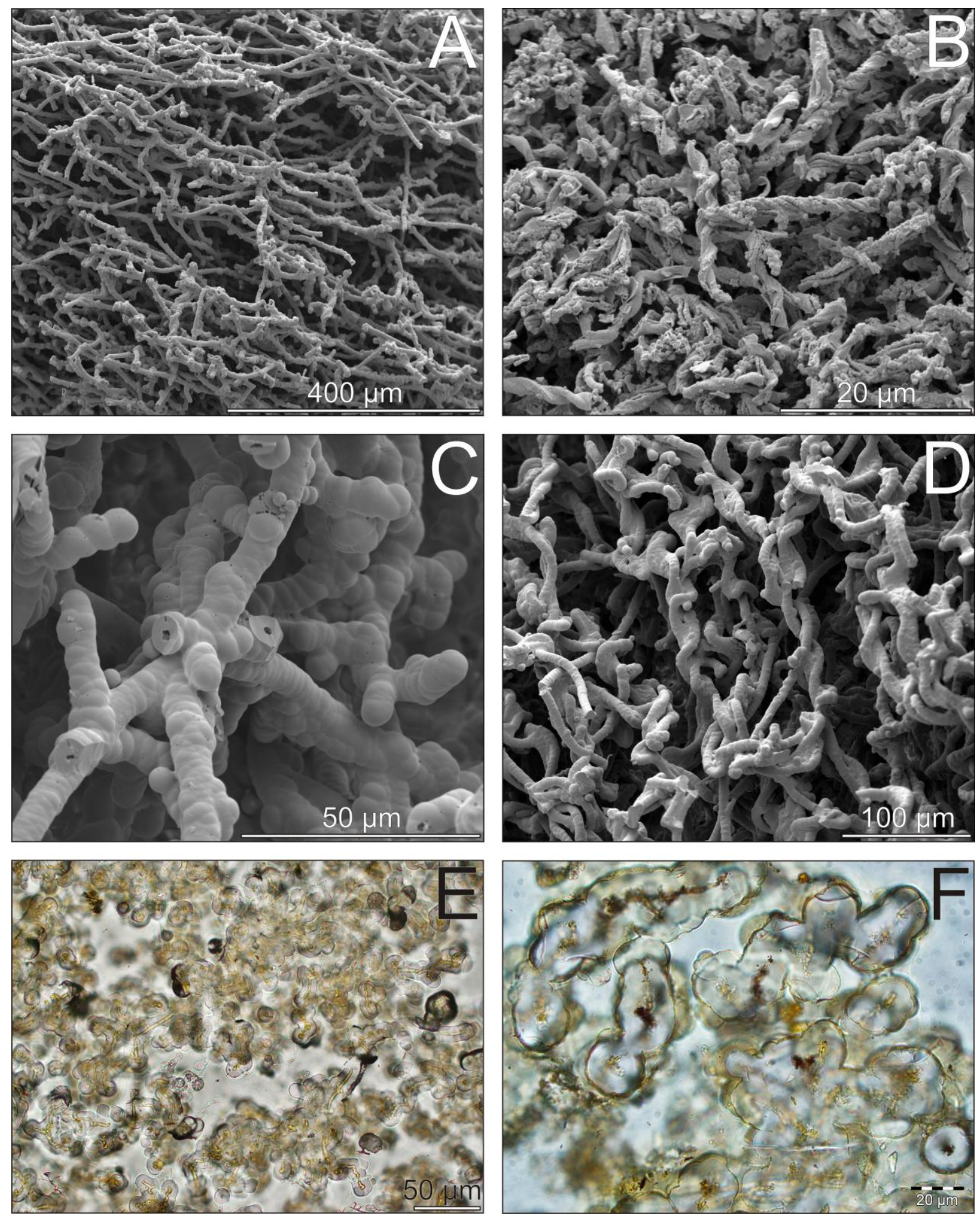

Fig. 3 

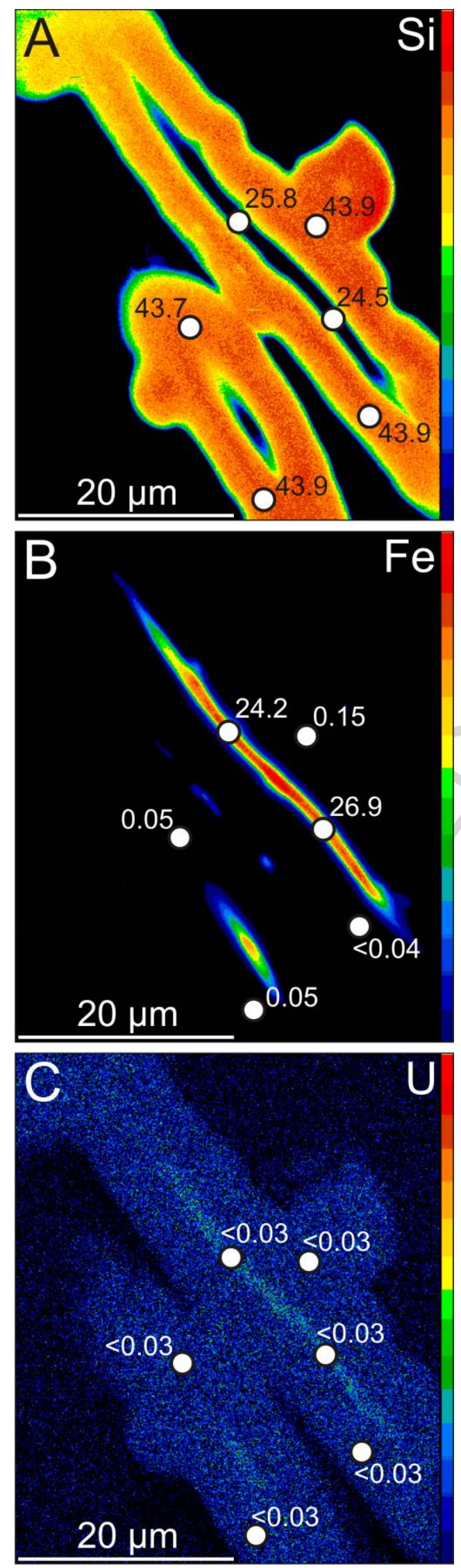

Fig. 4 

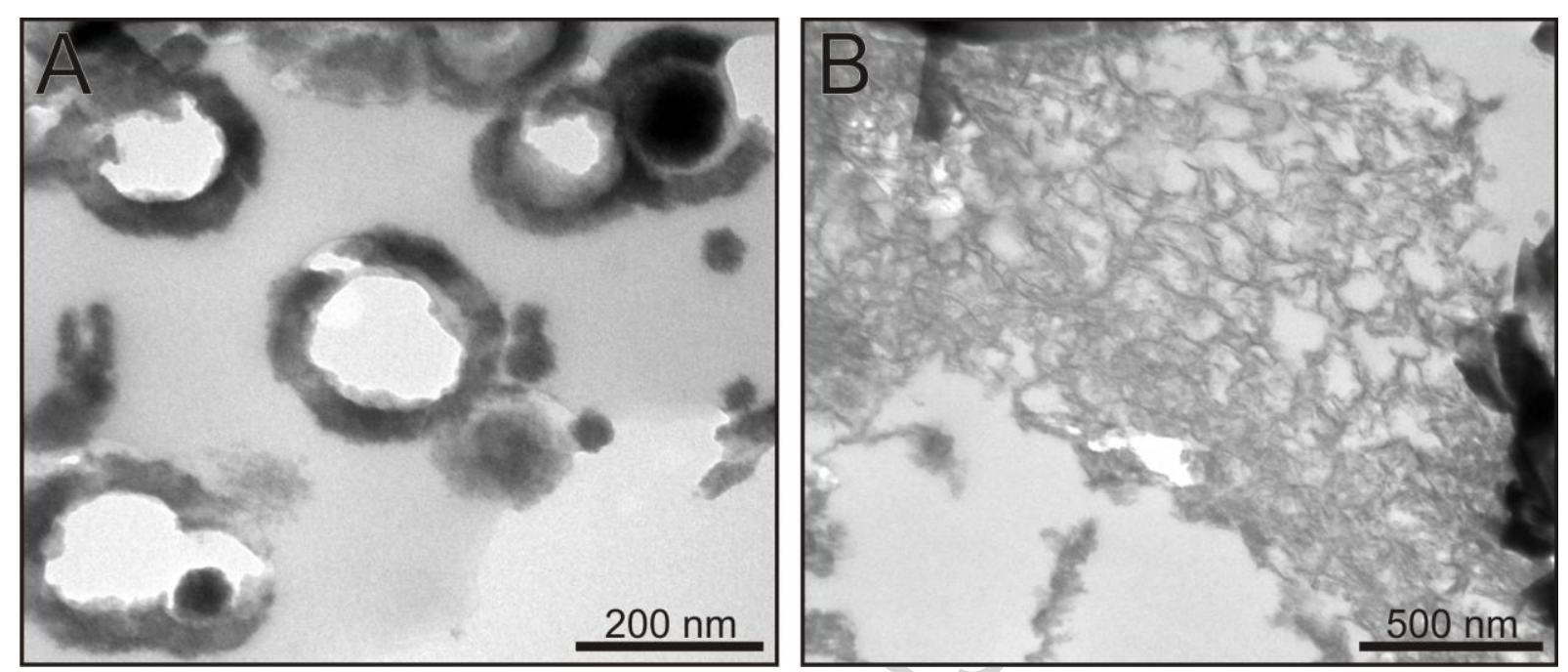

Fig. 5

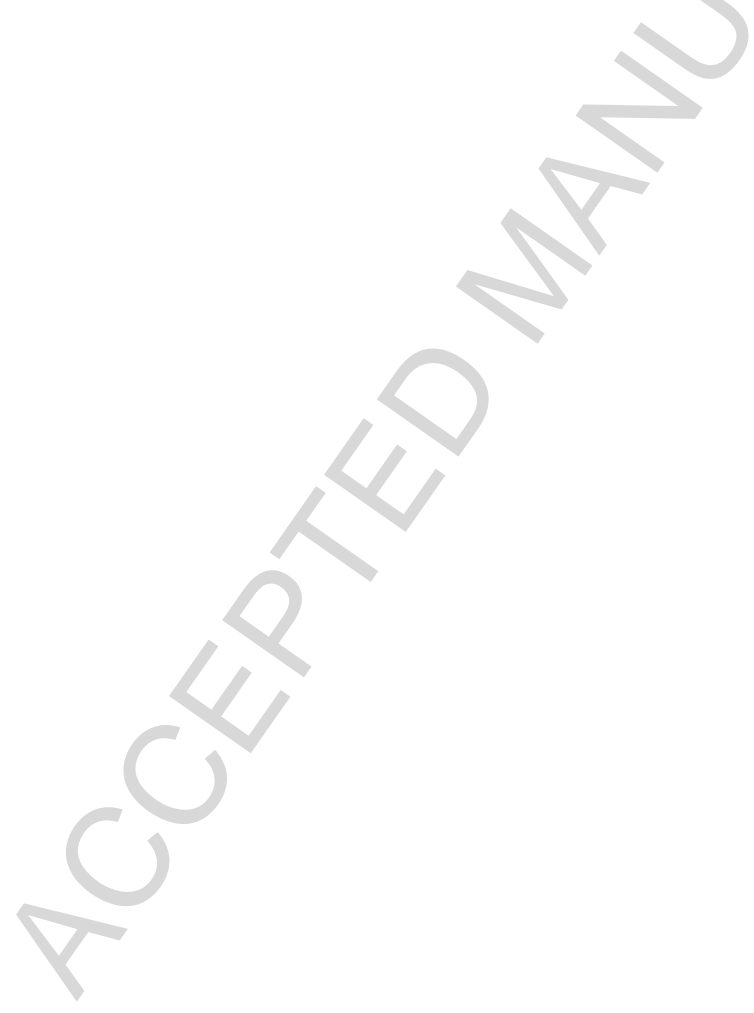



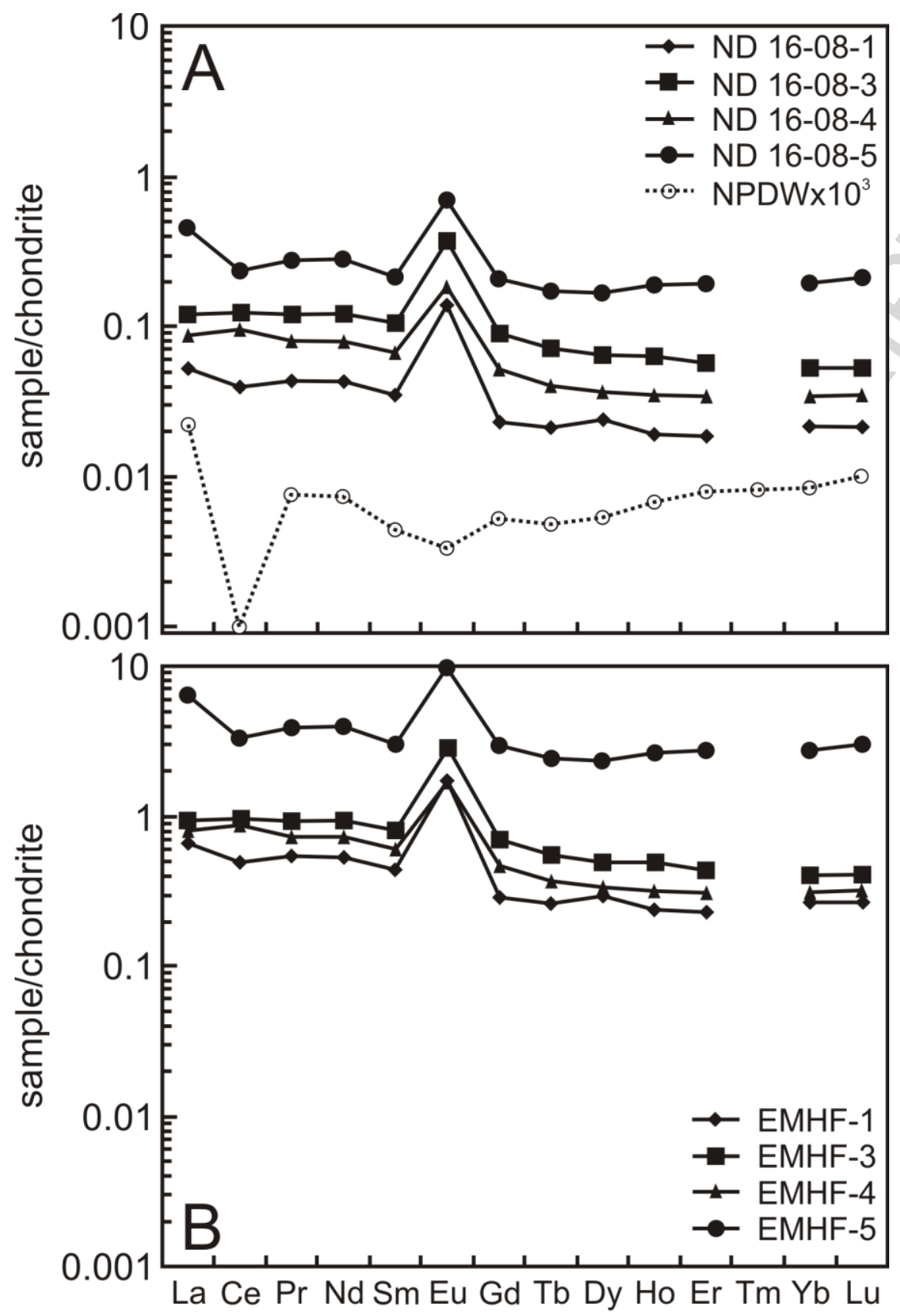

Fig. 6 


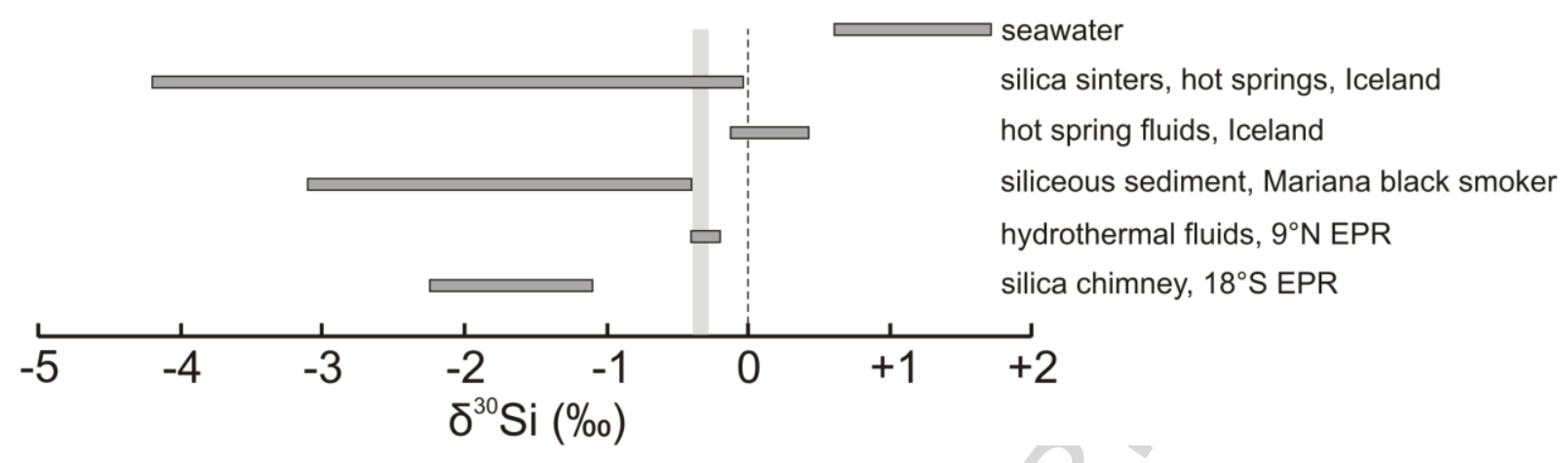

Fig. 7 


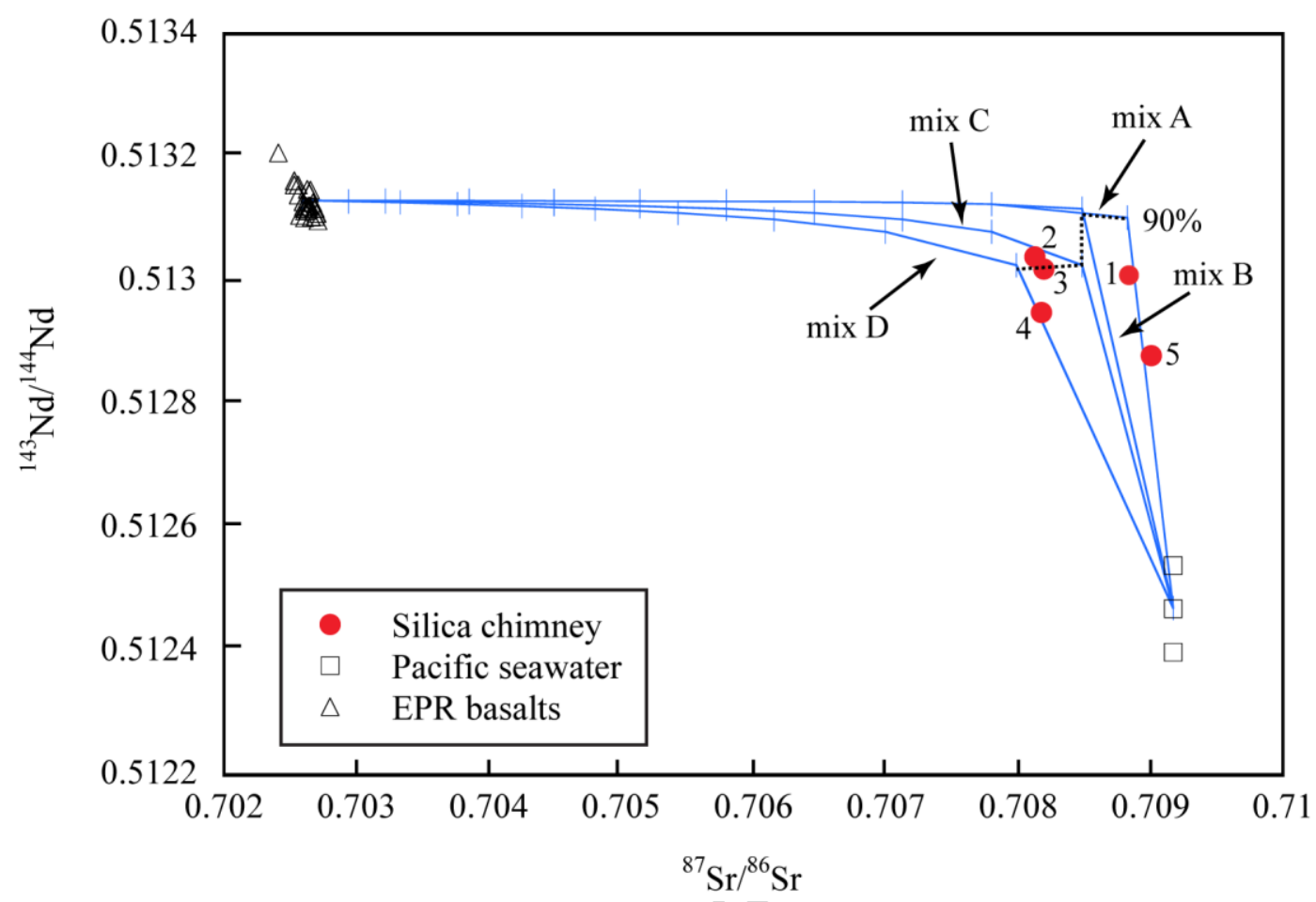

Fig. 8 


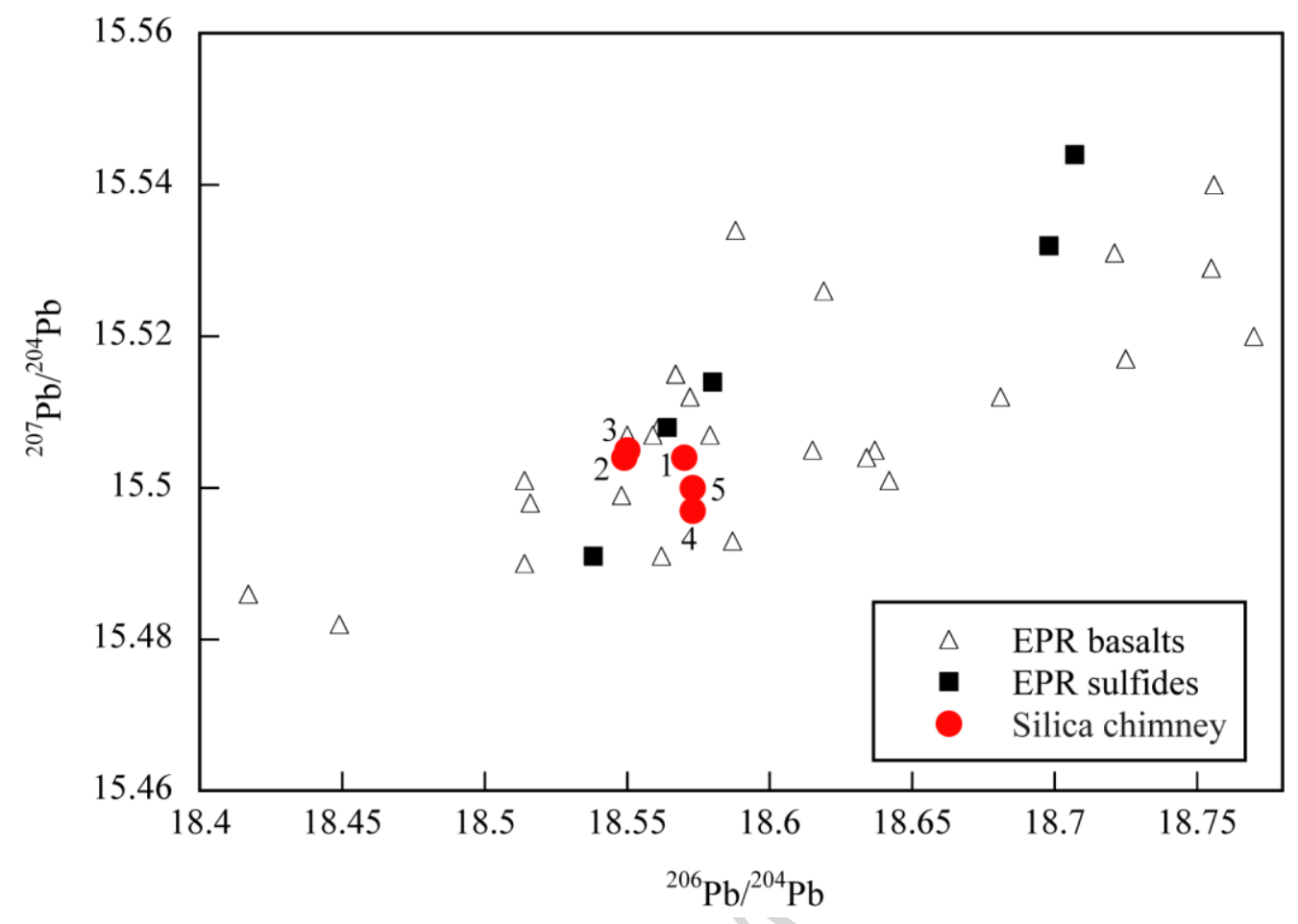

Fig. 9 


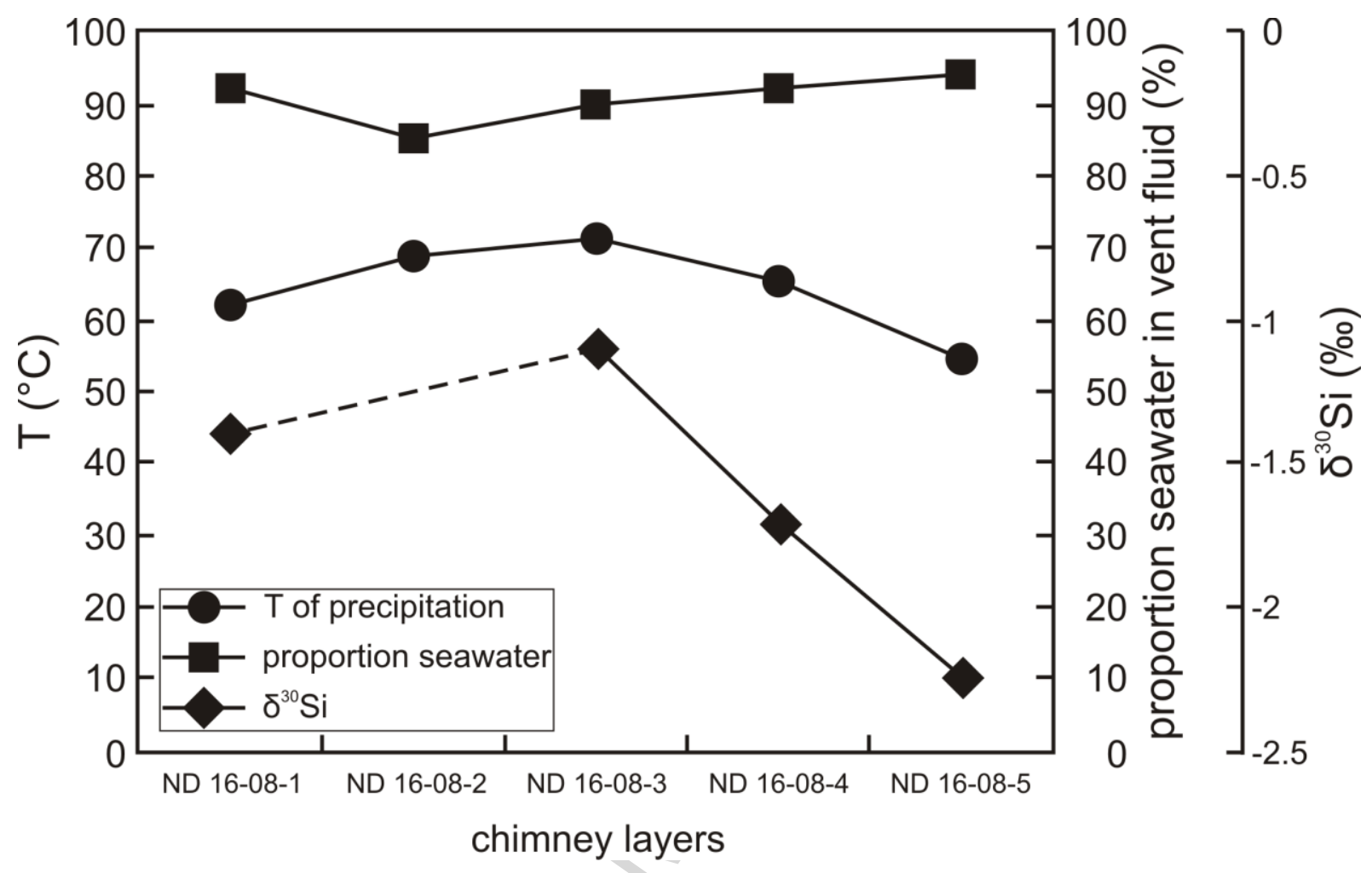

Fig. 10 
Table 1

Chemical composition (ICP-OES and HR-ICP-MS) of the inactive silica chimney \#ND 16-08.

\begin{tabular}{|c|c|c|c|c|c|}
\hline Sample ID & ND 16-08-1 & ND 16-08-2 & ND 16-08-3 & ND 16-08-4 & ND 16-08-5 \\
\hline $\mathrm{SiO}_{2}$, wt.\% & 93.6 & 91.8 & 94.0 & 93.9 & 88.2 \\
\hline $\mathrm{TiO}_{2}$ & 0.03 & 0.02 & 0.02 & 0.01 & 0.01 \\
\hline $\mathrm{Fe}_{2} \mathrm{O}_{3}$ & 1.8 & 2.0 & 2.1 & 2.6 & 5.4 \\
\hline $\mathrm{MgO}$ & 0.09 & 0.06 & 0.06 & 0.05 & 0.18 \\
\hline $\mathrm{Na}_{2} \mathrm{O}$ & 0.25 & 0.13 & 0.19 & 0.22 & 1.01 \\
\hline $\mathrm{K}_{2} \mathrm{O}$ & 0.03 & 0.03 & 0.03 & 0.03 & 0.06 \\
\hline $\mathrm{P}_{2} \mathrm{O}_{5}$ & 0.074 & 0.067 & 0.061 & 0.063 & 0.137 \\
\hline$S_{\text {tot }}^{a}$ & 0.21 & - & 0.11 & 0.26 & 1.20 \\
\hline $\mathrm{S}_{\text {org }}{ }^{\mathrm{a}}$ & 0.13 & - & 0.09 & 0.10 & 0.12 \\
\hline$S_{\text {inorg }}^{a}$ & 0.08 & - & 0.02 & 0.16 & 1.08 \\
\hline $\operatorname{TOC}^{\mathrm{a}}$ & 0.08 & - & 0.08 & 0.10 & 0.43 \\
\hline $\operatorname{TIC}^{\mathrm{a}}$ & $<0.01$ & - & $<0.01$ & 0.02 & 0.12 \\
\hline Al, ppm & 777 & 349 & 114 & 15.5 & 58.0 \\
\hline $\mathrm{Ca}$ & 442 & 331 & 238 & 277 & 862 \\
\hline $\mathrm{Mn}$ & 22.9 & 25.0 & 31.0 & 43.4 & 195 \\
\hline $\mathrm{Sr}$ & 6.41 & 6.26 & 5.11 & 7.85 & 35.6 \\
\hline $\mathrm{Ba}$ & 0.29 & - & 3.75 & 4.69 & 15.2 \\
\hline $\mathrm{Li}$ & 0.39 & 0.21 & 0.22 & 0.23 & 0.60 \\
\hline $\mathrm{Rb}$ & 0.67 & 0.44 & 0.35 & 0.28 & 0.55 \\
\hline Cs & $<0.06$ & $<0.06$ & $<0.06$ & $<0.06$ & $<0.06$ \\
\hline $\mathrm{Zr}$ & 5.17 & - & 0.08 & 0.08 & 0.39 \\
\hline $\mathrm{Hf}$ & $<0.07$ & $<0.07$ & $<0.07$ & $<0.07$ & $<0.07$ \\
\hline $\mathrm{Nb}$ & $<0.76$ & $<0.76$ & $<0.76$ & $<0.76$ & $<0.76$ \\
\hline Sc & $<0.09$ & $<0.09$ & $<0.09$ & $<0.09$ & $<0.09$ \\
\hline Sn & 7.26 & 16.9 & 13.5 & 5.44 & 4.68 \\
\hline W & $<4.81$ & $<4.81$ & $<4.81$ & $<4.81$ & $<4.81$ \\
\hline V & 1.29 & 1.16 & 1.72 & 1.98 & 10.1 \\
\hline $\mathrm{Cr}$ & 2.24 & 1.98 & 2.70 & 8.26 & 3.76 \\
\hline Co & 0.13 & 0.09 & 0.12 & 0.19 & 0.57 \\
\hline $\mathrm{Ni}$ & 23.7 & 5.85 & 25.3 & 16.3 & 13.6 \\
\hline $\mathrm{Cu}$ & 45.6 & 24.3 & 41.9 & 35.5 & 122 \\
\hline $\mathrm{Zn}$ & 14.6 & 5.66 & 8.96 & 14.9 & 76.6 \\
\hline $\mathrm{Cd}$ & 0.03 & $<0.01$ & 0.02 & 0.02 & 0.14 \\
\hline $\mathrm{Pb}$ & 6.07 & 3.40 & 3.20 & 6.91 & 26.0 \\
\hline $\mathrm{Ge}$ & $<2.52$ & $<2.52$ & $<2.52$ & $<2.52$ & 2.98 \\
\hline Ga & 3.54 & 2.12 & 0.91 & 0.04 & 0.24 \\
\hline As & 2.69 & 1.08 & 1.95 & 2.28 & 8.32 \\
\hline $\mathrm{Sb}$ & 0.37 & 0.29 & 0.25 & 0.30 & 0.66 \\
\hline $\mathrm{Se}$ & $<0.41$ & $<0.41$ & $<0.41$ & $<0.41$ & 0.86 \\
\hline Mo & $<1.66$ & $<1.66$ & $<1.66$ & $<1.66$ & 3.20 \\
\hline $\mathrm{TI}$ & 1.77 & 0.56 & 0.66 & $<0.52$ & 0.70 \\
\hline Th & 0.00034 & - & 0.00157 & 0.00138 & 0.00364 \\
\hline U & 28.8 & - & 26.4 & 8.61 & 10.4 \\
\hline $\mathrm{Re}$ & $<0.01$ & $<0.01$ & $<0.01$ & $<0.01$ & $<0.01$ \\
\hline La & 0.013 & - & 0.029 & 0.021 & 0.107 \\
\hline $\mathrm{Ce}$ & 0.024 & - & 0.077 & 0.059 & 0.143 \\
\hline $\mathrm{Pr}$ & 0.004 & - & 0.012 & 0.008 & 0.026 \\
\hline $\mathrm{Nd}$ & 0.020 & - & 0.057 & 0.037 & 0.132 \\
\hline Sm & 0.005 & - & 0.016 & 0.010 & 0.032 \\
\hline $\mathrm{Eu}$ & 0.008 & - & 0.022 & 0.011 & 0.040 \\
\hline $\mathrm{Gd}$ & 0.005 & - & 0.018 & 0.011 & 0.043 \\
\hline
\end{tabular}




\begin{tabular}{lrrrrr}
\hline $\mathrm{Tb}$ & 0.001 & - & 0.003 & 0.002 & 0.006 \\
$\mathrm{Dy}$ & 0.006 & - & 0.016 & 0.009 & 0.043 \\
$\mathrm{Ho}$ & 0.001 & - & 0.004 & 0.002 & 0.011 \\
$\mathrm{Er}$ & 0.003 & - & 0.009 & 0.006 & 0.032 \\
$\mathrm{Yb}$ & 0.004 & - & 0.009 & 0.006 & 0.033 \\
$\mathrm{Lu}$ & 0.0006 & - & 0.0014 & 0.0009 & 0.0054 \\
$\mathrm{Y}$ & 0.034 & - & 0.116 & 0.070 & 0.438 \\
$\Sigma \mathrm{REE}$ & 0.09 & - & 0.27 & 0.18 & 0.65 \\
$\left(\mathrm{Ce} / \mathrm{Ce}^{*}\right)^{\mathrm{b}}$ & 0.82 & - & 1.04 & 1.14 & 0.64 \\
$(\mathrm{Eu} / \mathrm{Eu})^{\mathrm{C}}$ & 4.81 & - & 3.82 & 3.11 & 3.30 \\
$\mathrm{La}_{\mathrm{CN} / \mathrm{Lu}_{\mathrm{CN}}}$ & 2.44 & - & 2.27 & 2.54 & 2.12 \\
\hline $\mathrm{a}$ measured by Micro Cube elemental analyzer, see section 3 for details &
\end{tabular}

${ }^{a}$ measured by Micro Cube elemental analyzer, see section $\mathbf{3}$ for details

${ }^{\mathrm{b}} \mathrm{Ce} / \mathrm{Ce}{ }^{*}=2 \mathrm{Ce}_{\mathrm{CN}} /\left(\mathrm{La}_{\mathrm{CN}}+\operatorname{Pr}_{\mathrm{CN}}\right)$

${ }^{\mathrm{c}} \mathrm{Eu} / \mathrm{Eu}^{*}=2 \mathrm{Eu}_{\mathrm{CN}} /\left(\mathrm{Sm}_{\mathrm{CN}}+\mathrm{Gd}_{\mathrm{CN}}\right)$ 
Table 2

Isotope composition of the inactive silica chimney \#ND 16-08.

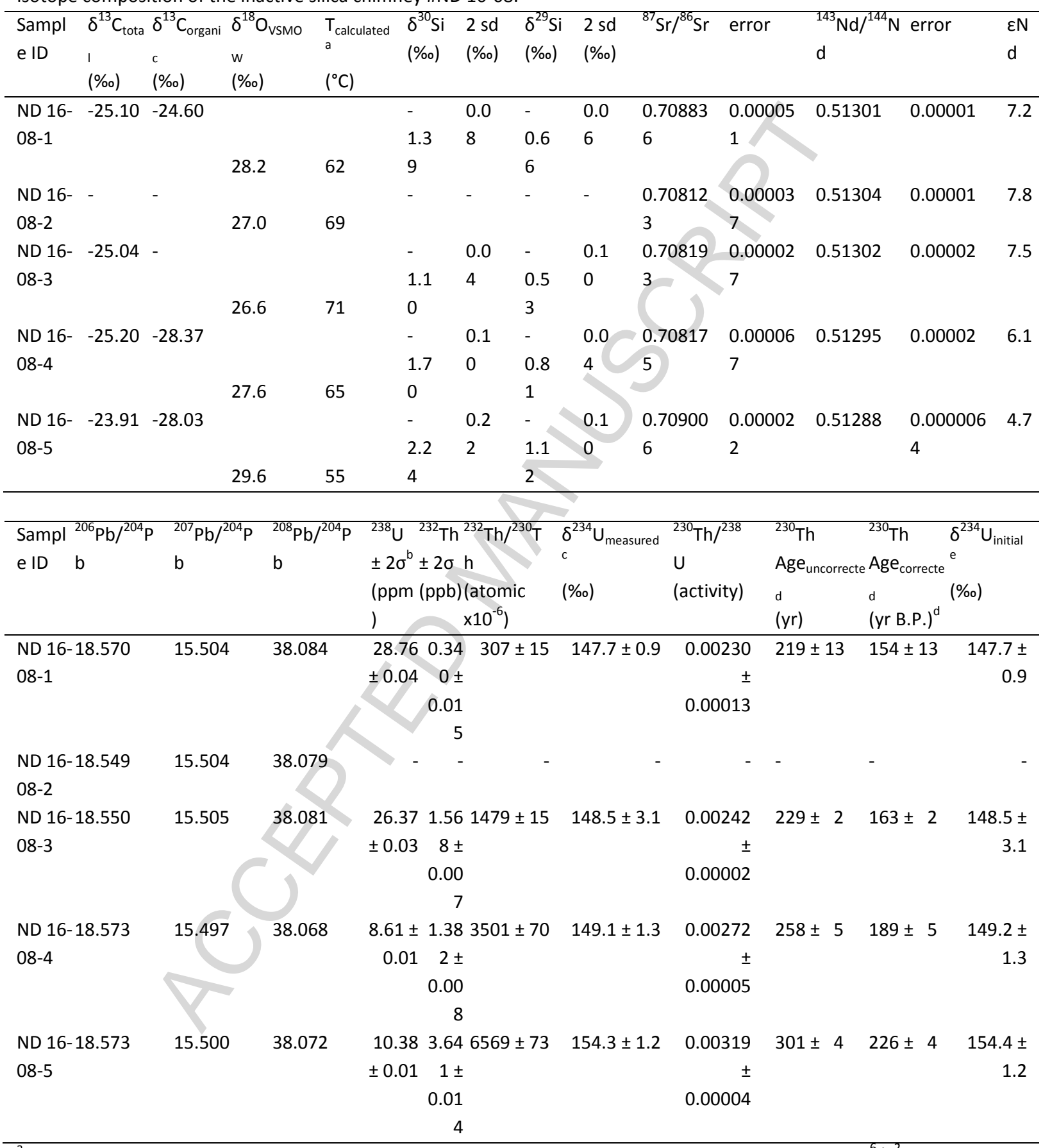

${ }^{a}$ Quartz-water oxygen isotope geothermometry equations from Clayton et al. (1972): $1000 \ln \alpha=3.38\left(10^{6} / \mathrm{T}^{2}\right)-2.90 ; \mathrm{T}^{\circ} \mathrm{C}=$ $\left[3.38 \times 10^{6} /(1000 \ln \alpha+2.9)\right]^{1 / 2}-273$. Assuming $\delta^{18} \mathrm{O}_{\text {water }}=1 \%$, which is the approximate average value for MOR hydrothermal vent fluids (Shanks, 2001).

${ }^{\mathrm{b}}$ All calculations of U-Th data have used the half-lives measured by Cheng et al. (2013).

${ }^{\mathrm{c}} \delta^{234} \mathrm{U}=\left[\left(^{234} \mathrm{U} /{ }^{238} \mathrm{U}\right)\right.$ activity -1$] \times 1000$.

${ }^{d}$ Corrected ${ }^{230} \mathrm{Th}$ ages assume the initial ${ }^{232} \mathrm{Th} /{ }^{230} \mathrm{Th}$ atomic ratio of 185,000 (i.e., values for a material at secular equilibrium). B.P. stands for "Before Present" where the "Present" is defined as the year 1950 A.D.

${ }^{\mathrm{e}} \delta^{234} U_{\text {initial }}$ was calculated based on ${ }^{230} T$ h age $(T)$ : i.e., $\delta^{234} U_{\text {initial }}=\delta^{234} U_{\text {measured }} \times \mathrm{e}\left(\lambda^{234} \mathrm{xT}\right)$. 
Table 3

Average chemical composition of silica chimneys from different geological settings.

\begin{tabular}{|c|c|c|c|c|c|c|}
\hline $\begin{array}{l}\text { Chimney } \\
\text { ID }\end{array}$ & ND 16-08 & $\begin{array}{l}\text { C, Cauliflower } \\
\text { Garden }\end{array}$ & $1895-11$ & 31GTV & L13 & Bridge Bay spires \\
\hline Location & $\begin{array}{l}\text { south East } \\
\text { Pacific Rise }\end{array}$ & $\begin{array}{l}\text { Galapagos } \\
\text { spreading centre }\end{array}$ & $\begin{array}{l}\text { Sumisu Rift, Izu- } \\
\text { Bonin Arc }\end{array}$ & Mariana Trough & Lau Basin & Yellowstone Lake \\
\hline $\begin{array}{l}\text { Geological } \\
\text { setting }\end{array}$ & $\begin{array}{l}\text { mid-ocean } \\
\text { ridge }\end{array}$ & mid-ocean ridge & $\begin{array}{l}\text { back-arc } \\
\text { spreading } \\
\text { centre }\end{array}$ & $\begin{array}{l}\text { back-arc spreading } \\
\text { centre }\end{array}$ & $\begin{array}{l}\text { back-arc spreading } \\
\text { centre }\end{array}$ & continental rift \\
\hline Source & this study & Herzig et al. (1988) & $\begin{array}{l}\text { Urabe and } \\
\text { Kusakabe } \\
(1990)\end{array}$ & $\begin{array}{l}\text { Stüben et al. } \\
(1994)\end{array}$ & Sun et al. (2012) & $\begin{array}{l}\text { Shanks et al. } \\
(2005)\end{array}$ \\
\hline $\mathrm{SiO}_{2}$, wt. $\%$ & 92.3 & 91.7 & - & 90.2 & 67.6 & 83.6 \\
\hline $\mathrm{TiO}_{2}$ & 0.02 & - & - & 0.03 & 0.01 & 0.12 \\
\hline $\mathrm{Fe}_{2} \mathrm{O}_{3}$ & 2.78 & 2.24 & 8.28 & 6.98 & 13.5 & 3.00 \\
\hline $\mathrm{MgO}$ & 0.09 & 0.19 & - & 0.54 & 0.67 & 0.41 \\
\hline $\mathrm{Na}_{2} \mathrm{O}$ & 0.36 & 0.67 & . & 0.24 & 2.28 & 0.44 \\
\hline $\mathrm{K}_{2} \mathrm{O}$ & 0.04 & 0.18 & & 0.24 & 0.44 & 0.40 \\
\hline $\mathrm{P}_{2} \mathrm{O}_{5}$ & 0.08 & 0.50 & & 0.06 & 0.43 & 0.48 \\
\hline Al, ppm & 263 & $<1059$ & & 4024 & 913 & 24565 \\
\hline $\mathrm{Ca}$ & 430 & 536 & - & 6862 & 6862 & 4575 \\
\hline $\mathrm{Mn}$ & 63.5 & 3089 & 269 & 29.6 & 26908 & 310 \\
\hline $\mathrm{Sr}$ & 12.2 & 135 & - & 1508 & 963 & 119 \\
\hline $\mathrm{Ba}$ & 5.98 & 2120 & 1555 & 4495 & 11115 & 1780 \\
\hline $\mathrm{Li}$ & 0.33 & & - & 0.70 & 70 & 21.7 \\
\hline $\mathrm{Rb}$ & 0.46 & & - & 2.62 & 4 & 12.9 \\
\hline Cs & $<0.06$ & & - & - & 0.42 & 4.83 \\
\hline $\mathrm{Zr}$ & 1.43 & - & - & - & 2.24 & 21.7 \\
\hline $\mathrm{Hf}$ & $<0.07$ & - & - & - & 0.05 & 0.60 \\
\hline $\mathrm{Nb}$ & $<0.76$ & - & - & - & 0.07 & 8.75 \\
\hline $\mathrm{Ta}$ & - & - & - & - & 0.12 & 0.10 \\
\hline Sc & $<0.09$ & - & - & - & 1.33 & 2.00 \\
\hline Sn & 9.56 & - & - & - & - & 0.70 \\
\hline W & $<4.81$ & - & - & 3.99 & - & 137 \\
\hline V & 3.25 & - & - & - & - & 66.3 \\
\hline $\mathrm{Cr}$ & 3.79 & - & - & - & 2.25 & - \\
\hline Co & 0.22 & 21.3 & - & 5.23 & 11.3 & 13.3 \\
\hline $\mathrm{Ni}$ & 17.0 & - & - & 4.27 & 31.5 & 143 \\
\hline $\mathrm{Cu}$ & 53.9 & 28 & 85 & 5.85 & 1229 & 14.0 \\
\hline $\mathrm{Zn}$ & 24.1 & 35 & 137 & 13.1 & 1418 & 24.0 \\
\hline $\mathrm{Cd}$ & 0.05 & - & - & - & - & 0.55 \\
\hline $\mathrm{Pb}$ & 9.12 & - & 299 & 5.13 & 65 & 5.63 \\
\hline Ge & 2.98 & 10.7 & - & - & - & 2.70 \\
\hline $\mathrm{Ga}$ & 1.37 & - & - & - & - & 8.73 \\
\hline As & 3.26 & - & 137 & - & - & 563 \\
\hline $\mathrm{Sb}$ & 0.37 & - & 105 & - & - & 11.4 \\
\hline Mo & 3.2 & 20.4 & - & 56.5 & 209 & 15.6 \\
\hline $\mathrm{TI}$ & 0.92 & - & - & 21.6 & 13.4 & 9.10 \\
\hline Th & 0.002 & - & - & - & 0.03 & 2.03 \\
\hline U & 18.5 & - & - & 1.03 & 5.95 & 2.13 \\
\hline La & 0.042 & - & - & - & 1.31 & - \\
\hline $\mathrm{Ce}$ & 0.076 & - & - & - & 0.78 & - \\
\hline $\mathrm{Pr}$ & 0.012 & - & - & - & 0.19 & - \\
\hline $\mathrm{Nd}$ & 0.062 & - & - & - & 0.87 & - \\
\hline
\end{tabular}




\begin{tabular}{|c|c|c|c|c|c|c|}
\hline $\mathrm{Sm}$ & 0.016 & - & - & - & 0.29 & - \\
\hline $\mathrm{Eu}$ & 0.020 & - & - & - & 4.28 & - \\
\hline Gd & 0.019 & - & - & - & 0.40 & - \\
\hline $\mathrm{Tb}$ & 0.003 & - & - & - & 0.04 & - \\
\hline Dy & 0.019 & - & - & - & 0.24 & - \\
\hline Ho & 0.004 & - & - & - & 0.06 & - \\
\hline $\mathrm{Er}$ & 0.013 & - & - & - & 0.19 & - \\
\hline $\mathrm{Tm}$ & - & - & - & - & 0.03 & - \\
\hline $\mathrm{Yb}$ & 0.013 & - & - & - & 0.19 & - \\
\hline Lu & 0.002 & - & - & & 0.04 & - \\
\hline Y & 0.165 & - & - & & 2.55 & 9.05 \\
\hline ¿REE & 0.30 & - & - & & 8.89 & - \\
\hline$\left.(\mathrm{Ce} / \mathrm{Ce})^{*}\right)^{a}$ & 0.91 & - & - & 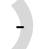 & 0.43 & - \\
\hline$\left(\mathrm{Eu} / \mathrm{Eu}^{*}\right)^{\mathrm{a}}$ & 3.76 & - & - & & 39.7 & - \\
\hline
\end{tabular}

${ }^{\mathrm{a}}$ See Table 1 for the calculations.

\section{Highlights}

- chimney is composed of silica-mineralized bacterial-like filaments;

- it grew from the most external layer towards the central chimney conduit;

- proportion of seawater within the venting fluid varied between 94 and 85\%;

- precipitation temperatures of the chimney layers varied between 55 and $71^{\circ} \mathrm{C}$;

- chimney is rich in $\mathrm{U}$ and poor in REE. 